folk/ed. Derg, 2021; 27(3)-107. sayı

DOI: $10.22559 /$ folklor.1850

Araştırma makalesi/Research article

\title{
Bir Çözümleme Yöntemi Olarak Sanatta Göstergelerarasılık
}

\section{The Intersemiotics as a Method of Art Analysis}

\section{Kubilay Aktulum*}

Öz

En az iki yazınsal metin arasındaki alışverişleri belirtmek için kullanılan metinlerarasılık kavramını yeni adlandırmalarla sanatın diğer biçimlerine uyarlayabiliriz: Örneğin, metinlerarasılık yanında resimlerarasılık, medyalararasılık, müziklerarasılık, sinemalararasılık, fotoğraflararasılık vb. adlandırmalar günümüzde yazın dışında başka alanlarda sıklıkla kullanılmaktadır. Bu adlandırmalara bağlı olarak, yenidenyazma, yenidenresmetme gibi kavramları alıntı, yansılama, öykünme, bilinçli esinlenme vb. kavramlarla birlikte sanatın diğer biçimleri konusunda da kullanabiliriz (bu konuda yapılan çalışmalarda böyle bir söz dağarına sıklıkla başvurulduğu görülmektedir). Bu çalışmada Gérard Genette'in Palimpsestes adlı yapıtında önerdiği tiplemeyi dönüştürerek kimi sanatsal biçimlerde kullanacağız. Örneğin, resim alanında resimlerarasılığın değişik biçimlerinden, dolayısıyla, iki ayrı gösterge dizgesi arasındaki alışverişleri

Geliş tarihi (Received): 18.04.2021 - Kabul tarihi (Accepted): 09.07.2021

* Prof.Dr., Hacettepe Üniversitesi Edebiyat Fakültesi Fransız Dili ve Edebiyatı Bölümü.Hacettepe University Faculty of Letters, Department of French Language and Literature. aktulumk@yahoo.com. ORCID 0000-0001-9929-937X 
belirtmek için kullanılan resimsel aşkınlık biçimleri konusunda yeni bir tiplemeden söz edebiliriz. Buna göre değişik göstergelerarasılık biçimlerinden söz edilebilir. Bunlar yazınsal bir dizgenin başka bir göstergeler dizgesine aktarımı olabileceği gibi, tersine bir yönelimde de gerçekleşebilir. Kökeni Ferdinand de Saussure'ün Genel Dilbilim Dersleri'ndeki gösterge kavramına uzanan ve Roman Jakobson'un göstergelerarası çeviri kavramından esinlenilerek sanatın değişik biçimlerine uyarlanan göstergelerarasılık yazınsal metinleri olduğu kadar değişik sanatsal biçimlerin aralarındaki alışverişleri çözümlemeye dayanan bir yöntem ortaya koyma çabasının bir ürünüdür. Bu çalışmada bir çözümleme yöntemi olarak sınırlı da olsa sanatın değişik biçimlerinde göstergelerarasılığın kullanımına ve kimi kavramlarına yönelik tanımlamalar yapılacaktır.

Anahtar sözcükler: metinlerarasılık, göstergelerarasılık, dönüştürme, Genette, palempsest, Godard

\begin{abstract}
We can adapt the concept of intertextuality, which is used to indicate the exchanges between at least two literary texts, to other forms of art with new denominations: For example, intertextuality as well as inter-picturality, intermediality, intermusicality, interfilmicity, interphotography, etc. denominations are frequently used in other fields apart from literature today. Depending on these namings, concepts such as rewriting, repainting are used as quotation, reflection, imitation, conscious inspiration, etc. We can also use it for other forms of art along with concepts (it is seen that such a vocabulary is frequently used in studies on this subject). In this study, we will transform the typology suggested by Gérard Genette in his work Palimpsestes and use it in some artistic forms. For example, we can talk about the different forms of interpictoriality in the field of painting, hence a new typing of the forms of pictorial transcendence used to denote the exchanges between two different sign systems. Accordingly, different forms of intersemiotics can be mentioned. These can be the transfer of a literary system to another sign system, or they can take place in the opposite direction. Intersemiotics, whose origin goes back to the concept of sign in Ferdinand de Saussure's Course in General Linguistics and adapted to different forms of art inspired by Roman Jakobson's concept of intersemiotic translation, is a product of an effort to present a method based on analyzing the exchanges between different artistic forms as well as literary texts. In this study, although limited as an analysis method, definitions will be made for the use of intersemiotics in different forms of art and some of its concepts.
\end{abstract}

Keywords: intertextuality, intersemiotics, transformation, Genette, palimpsestes, Godard 


\section{Extended summary}

We can use the concept of intertextuality in other forms of art with new denominations: for example, intertextuality as well as interpictoriality, intermediality, intermusicality, interfilmicity, interphotographicity etc. These denominations are frequently used in other fields apart from literature today. Depending on these namings, concepts such as rewriting, repainting are used as quotation, imitation, conscious inspiration, etc. We can also use them with concepts and other forms of art. In this article, we propose to transform the typology proposed by Genette on intertextual exchanges in Palimpsestes and use them in other areas of art. For example, we can talk about the different forms of interpictoriality in the field of painting, hence a new typing of the forms of pictorial transcendence used to denote the exchanges between two different sign systems. Accordingly, different forms of intersemiotics can be mentioned. These can be transfer of a literary system to another sign system, or they can take place in the opposite direction. Intersemioticity is an effort to present a method based on analyzing the exchanges between different artistic forms as well as literary texts. In this study, definitions will be made for the use of intersemiotics in different forms of art and some of its concepts as an analysis method.

The heterogeneity we find in the nature of intertextual and, accordingly, intersemiotics relations makes it necessary to make a comparison between the attitude adopted in classical aesthetics and the new perspective on aesthetics, thus revealing a series of similarities as well as differences. Such a comparison will allow to understand the specificity of intersemiotics. Accordingly, it was desired to be based on a series of basic principles in accordance with the principle of aesthetic clarity, which is in the field of work of analytic philosophy, thus trying to determine the unchanging structures of the work of art. Continuing the scientific and therefore logical analysis tendency of philosophy, structuralism tends to evaluate the work of art as a closed system within its inner workings and to grasp the forms of articulation. Thus, it adheres to the analytical principles of analytic philosophy. Until the 1960s, he adhered to the systematizing trend in Saussure's "Course in General Linguistics". However, after this date, the destiny of the artwork, which started to go beyond being a representation of a simple expressiveness and display, based on singularity with formal games, began to evolve towards plurality. This is one of the ways to pluralize meaning. Aesthetics, which tries to bind art to the rules and benefits from the analytical view of philosophy, continues to live in new phenomena related to the existence of the work of art. Its conditions change, and as it changes, its meaning changes. In accordance with the conditions described as postmodern, the work of art like aesthetics becomes open to the use of a "meta-language". Self-talking art and aesthetics are now one of the possible contents of a work of art. The work of art and the concept of beauty associated with it are an accidental or blind exaltation, presenting reality as it is by making it the main subject of the content, etc. It goes beyond classical understandings in the form of a problem in its own right. The old aesthetic leaves its place to a new aesthetic, a sense of aesthetics. The concept becomes plural, depending on it, the methods of reading or interpretation are diversified.

Parallel to Saussure's definitions, the work of art or aesthetic object is intended to be 
grasped as a structure, a special language. Thus, it reveals its value according to the new understanding. Its structure is defined through its operation. With an attitude inspired first by Saussure and then by the Russian Formalists, the approach that puts subjectivity forward in the historical process, starting from the 1960s, begins to put the structure forward. It is an attitude adopted by art and literature critics to position the work of art in front of its similars, to grasp its specificity in this respect, and to try to understand the universality of the work in this way. With this new approach, which also takes into account the audience, an open work aesthetic, as mentioned by Umberto Eco, emerges.

Artworks called postmodern bring an understanding that turns away from the past (but does not exclude them, reproduces them in new contexts), excludes the classical aesthetic understanding, and places plurality at the center. The pluralization of the work also allows the reading to be pluralized. Accordingly, the reader, the viewer and the listener, who are focused on the argument that each reading is equivalent to the other, are given the freedom of interpretation. Thus, a phenomenological reading, which puts the subject forward and is based on pluralizing the reality with the participation of different subjects, has become legal.

In the new conditions, the data of intertextuality as the most well-known method of postmodern works are analyzed by applying them to different disciplines.

\section{Giriş}

Bilindiği gibi, estetik, ayrı bir bilim dalı olmadan önce başlangıçta felsefenin temel uğraş konuları arasındaydı. Estetiğin felsefi bir görüngüde sorgulanması bildik bir eğilimdi. Analitik felsefe, kanıtlayıcı tutumu, savlarındaki açık seçiklikle bilimselliğin üzerine oturmayı hedeflerken hem görüngübilimsel (fenomenolojik) bir yaklaşıma hem de sanat karşısında dinsel bir katılıma karşı çıkıyor, betimsel bir bakış açısının ötesine geçerek anlamı etken kılmaya uğraşıyor, sanat yapıtının, dolayısıyla güzellik deneyiminin indirgenemez yapılarını belirlemeye uğraşıyordu. Bilimsellik söz konusu olduğunda bu anlaşılır bir öneridir. Anlaşılabilir olduğu kadar da tartışılabilir. Aynı zamanda yapısalcılık olarak adlandırılan sorgulama biçimine uyan, buna karşın postyapısalcılık olarak adlandırılan yaklaşıma pek çok bakımdan aykırı düşen bir öneri söz konusudur.

Felsefi eğilimleri kuşku götürmeyen yapısalcılık, ${ }^{1}$ Saussure'ün Genel Dilbilim Dersleri'nde ${ }^{2}$ sunduğu kimi dilsel kavramları sanatsal ve yazınsal bağlamda dönüştürürken felsefenin bilimsel, dolayısıyla da mantıksal çözümleme eğilimini sürdürür. Sanat yapıtını kapalı bir dizge gibi okuyarak kendi içselliği içerisinde değerlendirmeyi, eklemleniş biçimleri arasından anlamı kavramayı amaçlar. XX. yüzyılla birlikte sanatın yeni biçimleri estetiğin çözümlemeye dayalı felsefi görüngüsüne uygun bir ortam sunar. ${ }^{3}$ Ta ki 1960'l1 yıllara kadar. Bu tarihe gelinceye değin aslında sanatın görünümünü durmaksızın yenilediği görülmektedir. "Moda" olarak adlandırılan yığınla sanatsal biçimin gelip geçmesi aslında sanatın kesinlemelere dayalı bilimsel bir tanımlamasını yapmaya olanak vermez. Yalın bir anlatımsallığın ve gösterimin temsili olmaktan öteye geçen sanat yapıtının biçimsel oyunlarla tekilliğe yaslanan yazgısı çoğulluğa doğru evrilmeye başlamıştır. Anlamı çoğullaştırmanın 
yollarından birisi de budur. Sanatı kurallara bağlamaya çalışan, felsefenin çözümsel bakışından yararlanan estetik, sanat yapıtının varoluşuna ilişkin yeni görüngülerde yaşamayı sürdürür. Koşulları değişir, değiştikçe anlamı da değişir. Postmodern olarak nitelenen koşullara uygun olarak estetik gibi sanat yapıtı bir "üst-dil" (fr. mélangage) ${ }^{4}$ kullanımına açık duruma gelir. Kendinden söz eden sanat ve estetik, sanat yapıtının olası içeriklerinden birisidir artık. Sanat yapıtı ve onunla birlikte anılan güzellik kavramı rastlantısal ya da körü körüne bir yüceltme, gerçekliği, içeriğin temel konusu yaparak olduğu gibi sunma vb. biçiminde klasik anlayışların ötesine geçerek kendi başına bir sorunsal durumuna gelir. Eski estetik, yerini yeni bir estetiğe, estetik anlayışına bırakır. Kavram çoğullaşır, ona bağlı olarak da okuma ya da yorumlama yöntemleri çeşitlenir.

Şu ya da bu sanatçının yapıtlarını estetik bir bağlamda sorgulamanın, sorgularken özgünlügünü kavramanın koşulu öncelikle estetiğe klasik bakışı, modern ve postmodern bakıştan ayıran yanları göz önünde bulundurmaktır. ${ }^{5}$

Estetik, kendi içinde ayrışı $\mathrm{k}^{6}$ bir kavramdır. Felsefe bağlamında tanımlanır görünse de kimi zaman mantıkla, etikle, siyasetle, toplumbilimle vb. ilişkileri içerisinde konumlandırılır. Tümüyle kendine özgü, özgül bir tutumu olduğunu söylemek alabildiğine güçtür. Estetik nesne ise gerçekliğin bir gösterimi, duyumsalın ya da dokunsalın anlatımı gibi görülse de aynı zamanda bir yapıdır; özel bir dildir. Kendine özgü içsel bir işleyişi vardır. Değerini böylelikle belli eder. Dolayısıyla sanat yapıtını ayrı bir "kendilik" olarak tanımlamayı zorunlu kılar. Bir içerik, belli bir maksada uygun olarak özel bir yapıya sokulduktan sonra estetik bir biçim ya da nesne durumuna gelir. Sanat yapıtının kendiliğgi, yapısıdır. Değerini de önce böylelikle ortaya koyar. Sanat yapıtı, salt bir güzellik düşüncesi üzerinden tanımlanmakla kalmayıp yapısı, işleyişi üzerinden de tanımlanır, tanımlanmalıdır. Salt gerçekliği ya da öznelliği dışa vuran soyut bir nesne değil, aynı zamanda bir yapıdır: özel bir yapı. ${ }^{8}$

Önce Saussure'den, ardından Rus Biçimcilerinden esinlenen bir tutumla, tarihsel süreçte öznellik yerine 1960’lı yıllardan başlayarak artık yapı öne alınır. Postmodern olarak adlandırılan dönemde buna üçüncü bir unsur eklenecektir: izleyici. Önceleri özneyi öne alarak gerçekleştirilen bir konumlandırma sanatçıyı Tanrı konumuna getirmeye yönelikti. Oysa yapıyı öne alan bir konumlandırmanın getirilerinden birisi söz konusu şu ya da bu yapıtın türsel anlamda özgüllüğünü daha iyi kavramaya olanak sağlamaktır. Böyle bir yönelim, sanatçıyı ötekilere göre konumlandırmanın yanında, yeni bir adım önererek, yapıtı benzerleri karşısında konumlandırmaya, özgüllüklerini bu bakımdan kavramaya, yapıtın evrenselliğini böylelikle anlamaya olanak sağlar. Sanat yapıtının öznel bir üretim olduğu anlayışının yanına izleyici konularak onun (yapıtın) ortak bir üretim olduğu anlayışı getirilir. Umberto Eco'nun "açık yapıt" estetiği ile önerdiği budur. Bu yaklaşım sanatçının, yapıtını kendi esinine, yetilerine, kaynaklarına vb. göre ürettiği anlayışını tersine çevirir. Üretim sürecine izleyici de katılır. Romantik dönemin düşünü kurduğu, ben'i odağa alan, sanatçıyı başköşeye oturtan, özgünlüğü ve yeniliği sanatın ve sanatçının temel nesnesi yapan "dahi”"10 düşüncesi pek işlerlik kazanmaz; belli bir dönem kazandığı düşünülse de yaygınlaşmaz. İzleyicinin, anlamın dayatıldığı edilgen varlık olarak konumu tersine döner, izleyici yapıt karşısında etkin konuma gelir, dolayısıyla yapıttan alınan haz bu anlamda öznelleşir, özelleşir; her izleyicinin 
yapıttan aldığı haz farklılaşır. Değişik bakış açıları, algılama biçimleri devreye girer, yapıtın “çoğullaşması””ın olası yollarından birisi budur. Sanat yapıtı, dolayısıyla estetik, dinsel, törel, bilişsel vb. "geçişli" gelir. Bir başka anlatımla modernite, estetiği, sanatı özerkleştirme yoluna girer. Felsefeden bağını koparmaz, ancak algılanma biçimleri başka disiplinlerin verileriyle dönüşüp gelişir. Duyulurun bilimi olarak Baumgarten ${ }^{12}$ tarafından kuramlaştırılan estetik anlayışına bağlı olarak, neredeyse 1960'lı yıllara gelinceye değin sanat yapıtı, yapıyla ayrı türden bir haz verme çabası içerisine girer:

"Modern sanatın özellikleri arasında yaptığı beklenmedik ilerlemelerdeki yeniliği, el atılmamış alanları keşfi, alışılmış biçimlerin kökten yansınması, özyıkım, şok etkilerinin yoğunlaşması sayılabilir" (Cournarie, 2010:4).

Evrensel olarak hoşa gideni kavramlara indirgemenin olası olmadığını savlayan Kant'ın tanımlamasına koşut olarak sanat yapıtını belli kalıplara indirgeyerek, salt üreticisi açısından okuma anlayışı terk edilir. Yapıt, izlendikçe yeniden varlık kazanır anlayışı daha çekici gelmeye başlar. Kant'ın yaklaşımına uygun olarak söylersek, evrensellik öznelleşir. Haz, her türden bilişsel edinçten bağımsız bir biçimde anlatılır. Sanata klasik ve akademik bakışın dışlanması süreci böyle bir yaklaşıma özgüdür. Sanat yapıtını yeni koşullarda yeniden tanımlarken onun çoğulluğunu ele veren ayrıntıların betimlendiği göze çarpar. Çoğulluğu, onun türsel olarak konumlandırılmasını alabildiğine güçleştirir.

Modern sanat bu bakımdan sanat yapıtını belli bir kategoriye kesinkes bağlama girişimine de bir tür karşı çıkıştır. "Karma yapı", ${ }^{13}$ günümüzde adına postmodern denilen sanat yapıtının öne çıkan bir özelliğidir. Düzgüleri ters yüz etmek, bildik estetik alışkanlıkları yıkmak, yapıt karşısında yorum çeşitliliğine de olanak sağlamıştır. Her şeyin sanatın konusu olabilmesi, gereçlerin çeşitlenmesi, Gérard Genette'in söylediği gibi, "içkin nesnesinin"14 sürekli olarak yeni bir tanımlamaya uğraması sanatı kavramlaştırırken söz konusu çoğul okumaların da önünü alabildiğine aralamıştır. $\mathrm{Bu}$, göstermeye yönelik sanat yapıtından "demek isteyen"15 sanat yapıtı anlayışına geçiştir.

Modern sanat, artık bildik tanımlamaları yıkıp sürekli olarak yeni tanımlamalar önerirken yapıtın çoğulluğuna, çoğullaşmasına da hak verir gibidir. ${ }^{16}$ Çünkü varlığını sürdürmesi buna bağlıdır. Bu yaklaşım sanat yapıtını kesin değil geçici ve dönemsel tanımlamalara indirgemeye bir kapı aralamak, felsefi ve mantıksal tutumun kesinlik arayışının karşısına sakınımı çıkarmaktır. ${ }^{17}$ Amerikalı düşünür Morris Weitz, "Estetikte Kuramın Rolü“ adlı yazısında kesin tanımlamalar yapmanın olanaksızlığını tüm sanat yapıtları için ortak olabilecek yeterli iyenin olmamasına bağlar. ${ }^{18}$ Wittgenstein'dan esinlenerek sanat yapitları arasında ancak kimi benzerliklerin olabileceğinden söz eder:

"Estetikçiler benzerlik koşullarını pekâlâ sıralayabilirler, ancak kavramın doğru bir uygulamasını yapmak için gerekli ve yeterli koşulları asla sıralayamazlar. "Sanat" kavramıyla ilgili olarak söylersek, onun uygulanma koşulları hiçbir zaman tam olarak sıralanamaz çünkü doğası gereği, eski bir kavramı kenara itip, ya da yenisini 
bulup yaymak isteyecek sanatçılarca yeni durumlar öngörebilir ya da yaratabilir. (...) Benim savunduğum şey öyleyse sanatın şu yayılmacı, serüvenci özelliği, onun bitmek bilmeyen değişimleri ve yarattığı yeni şeyler, bu da mantıksal olarak belirleyici iyelikler toplamını garanti etmenin olanaksız olduğunu gösteriyor.”19

Morris Weitz'in savunduğu görüş yapısalcılıkla birlikte değişir. Kendi içsel unsurlarını, aralarındaki ilişkilere indirgemek gibi yapısalcı bir tutumdan uzaklaşılarak sanat yapıtını işleyişi, kendi içsel yapısı içerisinde gözlemlemek anlayışına doğru yol alınır. Nelson Goodmann da onu simgesel bir işleyiş olarak tanımlar. ${ }^{20}$ Karmaşık ve çok sayıda göndergeye yer vermesini simgesel işleyişin temel bir koşulu olarak görür. Orada göndergesel işlevler iç içe geçerek etkileşir. Bu, yapıta devingenlik kazandırmanın bir yoludur. Böyle bir tanımlama aynı zamanda yapısalcılığın, sanat yapıtını kapalı bir dizgeye indirgeyen anlayışını bir adım öteye (postmoderne) götürmek için atılan bir adımdır.

Gerçekten de postmodern olarak adlandırılan sanat yapıtları geçmişe yüz çeviren (ancak onları dışlamayan, yeni bağlamlarda yeniden üreten), klasik estetik anlayışı dışarıda bırakan, ${ }^{21}$ çoğulluğu başköşeye oturtan bir anlayış getirirler. Yapıtın çoğullaşması okumanın da çoğullaşmasına olanak sağlar. Buna göre her okumanın ötekine denk olduğu savıyla odağa alınan okura, izleyiciye, dinleyiciye yorum serbestliği tanınır. Özneyi öne alan, gerçeği değişik öznelerin katılımıyla çoğullaştırmaya dayanan görüngübilimsel (fenomenolojik) bir okuma benimsenen bir okuma modeli durumuna böylelikle gelmiştir.

En az iki resim arasındaki alışverişleri çözümlemeye dayanan resimlerarasılık yanında iki ayrı sanatsal biçim (resim ve sinema, resim ve müzik vb.) arasındaki alışverişleri belirtmek için kullanılan göstergelerarasıll $\mathrm{k}^{22}$ sürecine, bu sürecin işleyişine kavramsal ve yöntemsel bakımdan temel gereçleri sağlayan metinlerarasılığın, doğrudan izleyiciyi/okuru odağa alan görüngübilimsel bir tutuma bağlandığını anımsatalım. Gerçekten de Kubilay Aktulum'un altını çizdiği gibi, Michael Riffaterre kendi metinlerarasılık tanımlamalarında bu yanı öne çıkarır:

"Metinlerarası, okurun kendinden önce ya da sonra gelen bir yapıtta başka yapıtlar arasındaki ilişkileri algılamasıdır. Öteki yapıtlar ilk yapıtın metinlerarası göndergesini oluştururlar. $\mathrm{Bu}$ ilişkilerin algılanması öyleyse bir yapıtın yazınsallığının temel unsurlarından birisidir.”[...] “Alıntıdan kolaylıkla çıkarılabileceği gibi, yazınsal bir metin ile öteki metinler arasındaki ilişkiler okurca algılanmadıkça gerçekleşmez. Özel bir metin ile metinlerarası gönderge arasındaki ilişkileri okur kurduğuna göre, metinlerarası gönderge, 'okumaya başlar başlamaz çağrışımlar uyandıran metin' olarak kendini belli eden belirsiz bir bütündür” (Aktulum, 1999:61).

İzleyicinin algısına gereksinim duyan böyle bir çözümleme modelinde yapıtın değişik öznelerce alımlanmasına göre söz konusu ettiğimiz çoğullaşma yaratılır. Buna başka unsurlar eklenir. Başka yapıtlara ilişkin unsurları biçimsel ve anlamsal olarak dönüştürüp "yeni"23 bir yapıtta kullanmanın değişik yöntemlerinden söz edilir. Örneğin alıntı, yansılama, 
öykünme, kolaj, gönderge vd. ${ }^{24} \mathrm{Bu}$ ve benzeri kullanımlar ile bir yapıtın yüzeyinde değişik etkiler yaratılır. Örneğin, çoğullaşmadan başka, ayrışıklık, süreksizlik, senkretik (bireşimsel) yapılanma vd. Öyleyse değişik sanatsal biçimlerde alıntıdan, onların kendi aralarındaki alışverişlerinden, bir başka anlatımla göstergelerarasılıktan, yine bir başka anlatımla örneğin bir resmin değişik sanatsal biçimlerden gereçlerini tüketme ya da onlara kendi gereçlerini sunma olgusundan söz ederken başka yapıtlara ilişkin unsurların şu ya da bu yönteme göre önce biçimsel bakımdan uğradıkları dönüşümler, ardından bağlamsal dönüşüme bağlı olarak anlamsal dönüşümlerin neler olduğunu da belirlemek, ayrıca yazınsalın bağlamında tanımlanan kullanımları resmin alanına uyarlamak gerekir.

Hem resimlerarasılık hem de göstergelerarasılık kullanımında bir yapıtın tümünün ya da bir kesitinin bir bağlamdan alınıp başka bir bağlama taşınması bir aktarım işlemi gerçekleştirmektir. Bu işlemin sonucunda bağlam değiştiren şu ya da bu unsur biçimsel olmasa bile anlamsal bir dizi dönüşüme uğratılmaktadır. Resimlerin kendi aralarındaki alışverişlerine göre bağlamın değişmesi dolayımın (fr. médium) değişmesine olanak sağlamasa da, göstergelerarası bir bağlam değiştirmede dolayımın değiştiği, dolayısıyla, örneğin resimsel unsurların fotoğrafın, müziğin, yazınsalın, sinemasalın vb. alanlarına aktarımında alıntılama biçimlerinin doğalarının dönüştüğü, yapıtlardaki alışveriş biçimlerinin farklılaştığı görülür. Kısacası, resimlerarası aktarım ile göstergelerarası aktarımın işleyişlerinin birbirlerinden ayrı olduklarını gözden uzak bulundurmamak gerekir.

Buna karşın, ister resimlerarasılık ya da resimlerarası aktarım, ister göstergelerarasılık ya da göstergelerarası aktarım vb. olarak ayrılsın, her iki kullanım pek çok bakımdan farklılaştı̆̆ 1 gibi benzeşirler de. Benzeştikleri en temel yan her ikisinde de "alıntı” ya da "alıntılama" olgusunun baskın çıkmasıdır. Bu kısa tanımlamalara göre öyleyse değişik sanatsal biçimlerdeki alıntılama olgusunu şu biçimde şemalaştırabiliriz:

Resim ve Göstergelerarasılık: Resim ve Göstergelerarasılık denildiğinde en az üç terimi tanımlamak gerekiyor:

1-Metinlerarasılık: Metin 1+ Metin 2 (Ana-metin + Alt-metin)

2-Resimlerarasılık: $\quad$ Resim $1+$ Resim 2 (Ana-resim + Alt-resim)

3-Göstergelerarasılık: Resim + Sinema; Resim + Müzik; Resim + Metin vb.

Peki, nedir göstergelerarasılık olarak adlandırılan şey? Bu kavramı metinlerarasılık kavramı yanında, onu göz önünde bulundurarak tanımlamak gerekiyor.

Bir okuma (çözümleme) yöntemi olarak metinlerarasılığın verileri, sanatın diğer alanlarında da kullanılmaktadır. Günümüzde yalnızca yazınsal ya da dilsel olanın alanına özgü bir kavram olmakla kalmayarak çok sayıda farklı disiplin içerisinde (medya ve reklâmlarda), sanatın öteki biçimlerinde (tiyatro, dans, müzik, mimari, sinema, resim), uğraş alanlarının doğasına göre, yeniden tanımlanarak kullanılan metinlerarasılığın anlam ve kapsam alanı alabildiğine genişlemiştir.

Yazın dışındaki sanat biçimlerinin yazınsal olanla birlikte kendi aralarındaki 
alışverişlerini belirtmek için yeni kavramlar benimsenmiştir. Salt yazınsal alana özgü bir uygulama olmaktan çıkarak sanatın öteki biçimleri arasındaki alışveriş işlemlerini göstermek için, Saussure'ün "dil bir göstergeler dizgesidir" tanımından yola çıkan kimi dil, yazın, metin ve sanat kuramcılarınca (Jakobson, Molinié, Gignoux) göstergelerarasılık kavramı önerilmiştir. Böylelikle yazın ve resim, yazın ve sinema, yazın ve müzik, yazın ve fotoğraf; resim ve müzik, müzik ve resim, resim ve heykel, sinema ve resim vb. farklı sanatsal biçimler arasındaki alışveriş işlemleri, uçsuz bucaksız bir araştırma alanı, bir göstergelerarasılık başlığı altında, yeni bir açıdan sorgulanmaktadır. Gerçekten de yeni bakış açısıyla yazınlararasının yanı sıra sanatlararası (göstergelerarası) alışverişlerin de önünde neredeyse sınırsız bir sorgulama alanı aralanmaktadır.

Aralanmaması da olası değildir. Umberto Eco’yla birlikte alıntının, yinelemenin, sanatın neredeyse tüm biçimleri dışında, tüm yaşamımızı sardığı, belirlediği bir dönemde bulunuyoruz. Alıntı, yineleme, ödünçleme, aynı unsurun değişkeleri, aynı unsurun benzerini yapma işlemleri günlük yaşamımızda temel bir yönelim durumuna gelmiştir. Günümüzün postmodern olarak adlandırılan sanatçıları ve yazarları, önceki dönemlere ait yapıtları, kendi yapıtlarının bir çıkışı olarak almakta bir sakınca görmemektedirler; buna bağlı olarak yapıtlarında ötekine ait olanı, bir dönüştürüm işlemiyle genişleterek, yoğunlaştırarak ya da daraltarak çeşitli alıntı, alıntılama, yenidenyazma işlemlerine sıklıkla başvurmaktan da geri durmamaktadırlar. Alıntı, sanatsal alanda günümüzde olduğu kadar geçmişte de yapıtlararası, göstergelerarası alışverişler içerisinde olası dönüştürüm yöntemlerinden birisi olarak sıklıkla başvurulan yöntemler arasında yer almıştır ve almayı sürdürmektedir. Yazın dışında, örneğin resim alanında yenidenyazma (yenidenresmetme ya da resimlerarasılık), neredeyse benzer nedenlerle ötekinin yapıtını alıntılama işlemlerine yoğun olarak rastlanmaktadır.

Peki, iki ayrı yapıt arasındaki sorgulamada izlenebilecek bir çözümleme şeması nasıl oluşturulabilir? Madem ki en az iki yapıt arasında bir alışveriş işlemi söz konusu olacak; o zaman "alıntı" böyle bir alışveriş sürecinde temel unsurdur (buna elbette öykünme, yansılama, anıştırma, yalın bir gönderme, alaycı dönüştürüm vb. yöntemleri ekleyebiliriz.)

"En yalın biçimde, alıntı en az iki söylemi ya da iki resmi, Resim 1 (alıntılanan resim) ve Resim 2'yi (alıntılayan resim) bağıntıya getirir. Resim 1'de sözce (görsel bir unsur) ilk kez karşımıza çıkar (ve sözce bu resimden alınır); Resim 2'de sözce ikinci kez yinelenir. Alıntılanan sözce Resim 1 ve Resim 2 arasında alışveriş nesnesidir. Alıntı ayrıca iki ressamı öne çıkarır: Ressam 1 ve Ressam 2. Bunlar, alıntılanan sözcenin sözceleme özneleridir. Öteki resimlerarası biçimlere de uygulanabilecek bu alışveriş formülüne göre, alıntılanan sözce Resim 1 ve Resim 2'de aynı sözcedir; yineleyen sözceleme yinelenen sözcelemi değiştirmez. Bir başka deyişle, sözce aynı kalır ancak sözceleme değişir. Alıntılanan sözce, göstereni bakımından değişmez ise de maruz kaldığı yer değişikliğinden dolayı gösterilenini değişikliğe uğratır, yeni bir değer oluşturur ve hem alıntılanan resmin gösterilenini hem de içerisine sokulduğu yeni resmi etkileyen bir dönüşüme yol açar.

Bir sözcenin bir resimden (Resim 1) öteki resme (Resim 2) yer değiştirmesi iki resim arasında bir köprü kurar, bağ oluşturur. Baktin'in "söyleşim” adını verdiği bu olguya 
Compagnon "ilişki”" der. Bu, resimlerarası ilişki dediğimiz şeydir. Alıntı da iki resim arasında ilişki kurar. Ancak ilişkiyi kuran sözceleme, onu gerçekleştiren her iki resmin özneleri Özne 1 ve Özne 2 de doğrudan alıntıda yer alır. O halde alıntı yalnızca Resim 1 ve Resim 2 arasında bir ilişki değil, her biri bir resim ve bir ressamdan oluşan iki dizge yani Dizge 1 (Özne 1, Resim 1) ve Dizge 2 (Özne 2, Resim 2) arasındaki unsurların bir ilişsisinden ya da Baktin'in deyişiyle, bir söyleşiminden oluşur. İki dizge arasındaki ilişkiyi ressam kurar; onları saptamak ve anlamsal olarak işlevlerini çıkarmak ise okura düşer. (Ancak çoğu zaman bir resimde yalın ve açık olarak bulunan bir alıntı, izleyiciden özel bir kavrayış ya da aşırı bir bilgi birikimi gerektirmeden kendini belli eder. Alıntı, açık olduğundan saptanması kolaydır, ancak alıntıyı yorumlarken ve tanımlarken daha dikkatli yaklaşmak gerekir: Alıntılanan resmin seçimi, alıntının sınırları, montaj edilme biçimleri, yeni resimde ona verien anlam alıntının anlaşılması için gerekli unsurlardır.) Bir sözce olarak alıntının bir anlamı vardır, birinci dizgede bir düşünce açılar; yinelenen sözce olarak yine bir anlama sahiptir, ikinci dizgede de bir düşünce açıklar. Ancak hiçbir şey sözcenin her iki dizgede de aynı anlamda olduğunu kesinlememize olanak sağlamaz; her şey anlamın her iki dizgede de farklı olduğuna götürür" (Aktulum, 2016: 49 ). ${ }^{25}$

Böyle bir çözümleme, okuma şemasını oluşturduktan sonra sıra çözümlenecek yapıtlara geliyor. Burada bir iç resimsellik ya da resimlerarasılık çözümlemesine girişmeden, yalnızca "göstergelerarasılık" başlığı altında kimi yenidenüretim kullanımlarına değinmekle yetineceğiz. Örneklerimizi sinemadan ve fotoğraftan seçeceğiz (burada bütüncül değil, parçalı bir söylem biçimi yeğliyoruz, amacımız göstergelerarasılık olgusunu, resmin verilerinden yararlanarak, somutlaştırmaktır).

\section{Resim ve Fotoğraf:}

Günümüzde, ötekinin ürettiği görüntüleri alıntılamak, alıntılanan bir görüntüyü başka bir bağlama aktarmak "aracı unsurun" (medium) ya da, estetik bir bağlamda, "dolayım" denilen şeyin dönüştürülmesi demektir. Örneğin, Adad Hannah (Görsel 2), Géricault‘un Medusa'nın Salı (Görsel 1) adlı resmini fotoğraflayarak yeniden kurgularken pek çok başka sanatçı gibi alıntılanan görüntüden ayrı bir dolayım seçer, sanatı kendince, kendi bağlamında yeniden yaratır. ${ }^{26}$ Peki, neden bu yola başvurmaktadır? Göstergelerarası uygulama ona ne kazandırmaktadır?

Adad Hannah, ötekini alıntılarken önce onunla özdeşleşmek, onun yaratıcı sürecine katılmak, modelin değerini kavramak ister. Aynı zamanda, görüntülerle oynayarak gerçeği kendi imgeleminde yeniden kurgulayarak yaşar. Uzlaşılar karşısındaki konumunu böylelikle yeniler. Eskiyi olduğu gibi sürdürmek yerine kendi bağlamına taşıyarak günceller (her göstergelerarası uygulamada varılmak istenen, eski bir yapıtı ölmekten, unutulmaktan kurtarmaktır). Güncele taşıyarak ona yeni bir güç katma yolu budur. Ayrıca, eski dönem yapıtları, yaratıcılığa bir engel değil, gerekçe olurlar; imgelemi dürterler. Adad Hannah 
olduğu kadar, şu ya da bu sanatçıya, ötekiyle özdeşleşirken sanat tarihi içerisinde kendi yerini belirlemesine olanak sağlarlar. Bir başka getirisi de şudur: Geçmişi yok saymadan, bir sanatçı (burada Adad Hannah) onu kendi koşullarıyla buluşturarak hem ona yeniden can verir hem de, bir estetik düzlemde, çoksesliliğin kapısını aralar. Postmodern denilen şu şeyin, peşinden gittiği, arayışına çıktığı bu değil midir?

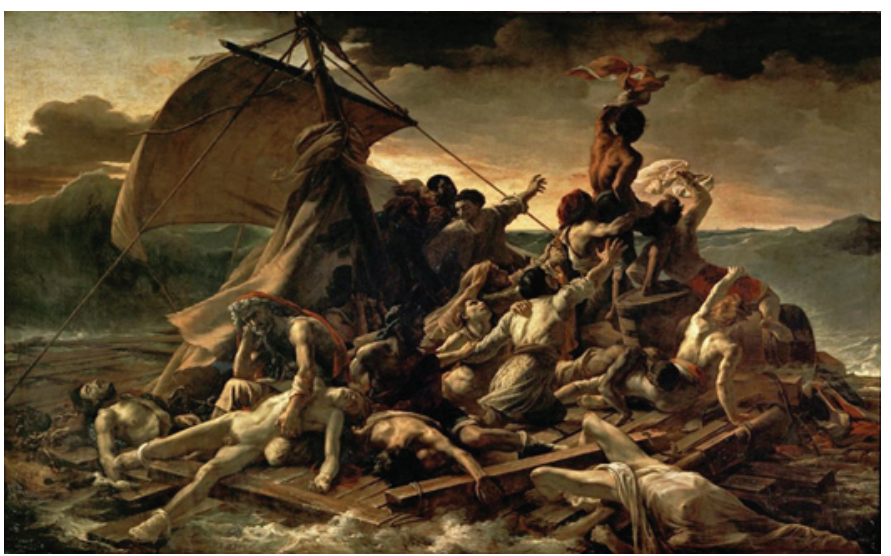

Görsel 1. Théodore Géricault, 1818-1819, le Radeau de la Méduse/Medusa'nın Sal1 ${ }^{27}$

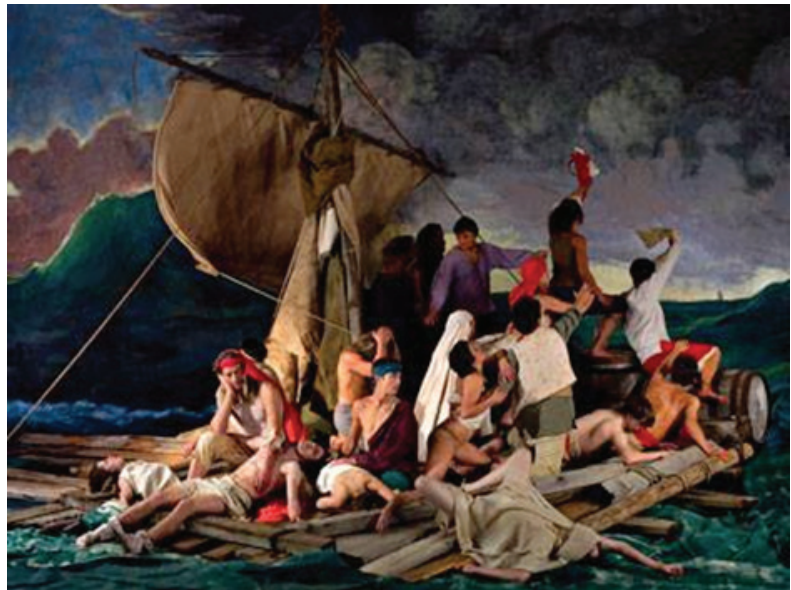

Görsel 2. Adah Hannah, 2009, The Raft of the Medusa/Medusa'nın Sal1 ${ }^{28}$

Benzer biçimde, İngiliz fotoğraf sanatçısı Tom Hunter, Velasquez, Caravage, Gaugin gibi pek çok sanatçının resimlerini canlı resimler biçiminde fotoğraflarken yoksulluk, şiddet, hayat kadınlığı, konut sorunu, kenar mahallelerde yaşayan kesimlerin sorunlarını güncele taşır. Sıradan insanların yaşam biçimleri onun başlıca konusudur. Eski ressamların resimlerini bunun için yeniden kullanır. Resimleri olduğu gibi yinelemez; kimi zaman bir resimden bir kesiti, bir görüntüyü, imgeyi alır. Sanayileşmenin yarattığı çöküşü itilmiş 
insanların yaşamlarını melankolik bir güzellik arasından yansıtmak ister. Londra'nın en kötü bölgesi Hackney hem bir yaşam hem de bir ölüm uzamıdır o ve ötekiler için. Bu mahalle, kültürel geri kalmışlı̆̆ın simgesidir. Neredeyse terk edilmiştir. Örneğin, John Millais’nin Ophelia'sında görülen (Görsel 4), bir kanala düşerek boğulan ya da öldürülen genç bir kızın görüntüsü ile (Görüntü 3) banliyödeki iç bulandırıcı ortama anıştırma yapılır. ${ }^{29}$ Kızın güzelliği sanayileşmenin çirkinliği ile çelişir. Yeniden üretilen her fotoğrafın eski resimler üzerinden anlattıkları kısa birer öyküleri bulunmaktadır. Alıntılanan eski resimleri okuyamadan T. Hunter'ın fotoğraflarını okumak olası değildir.

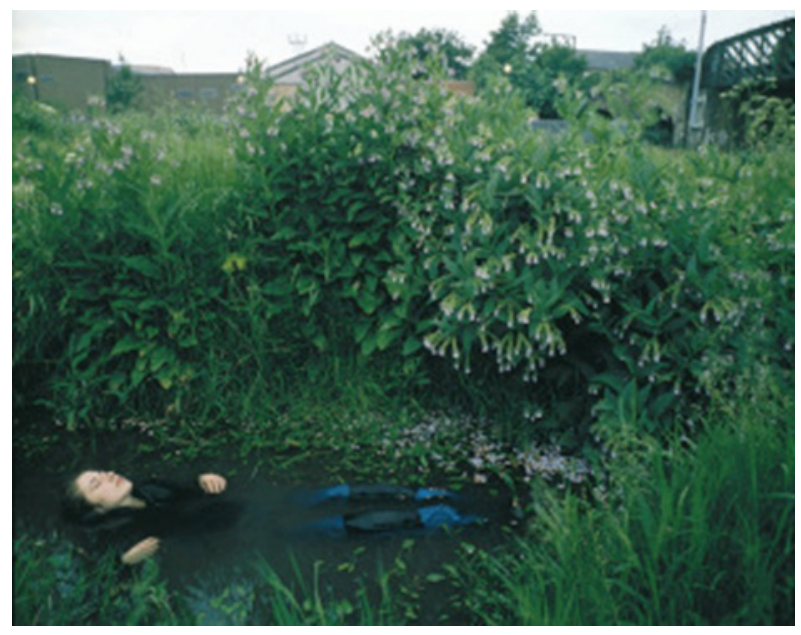

Görsel 3. Tom Hunter, 2012, The Way Home/Evin Yolunda ${ }^{30}$

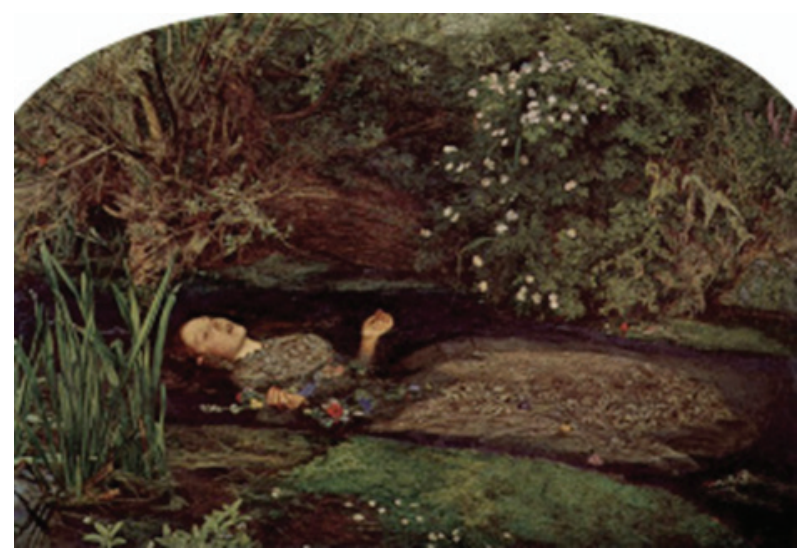

Görsel 4. John Everett Millais, 1851-1852, Ophelia ${ }^{31}$

\section{Resim ve Sinema}


Göstergelerarası uygulamalara sıklıkla rastlanan sanatsal biçimlerden birisi de sinemadır. Sinemada resme en fazla yer veren yönetmenlerden birisi Jean-Luc Godard' dır. ${ }^{32}$ Resimlerdeki coşkuyu kendince somutlaştıran J.L. Godard'ın çabası sinemada ne anlatmaktan çok nasıl anlatmak gerektiği sorusuna yanıt aramaktır. Sinema resim ilişkisini daha çok Passion'da (Çile 1982) sorgular. Filmde, sinema ve resim arasındaki ilişkiler değişik biçimlerde, 1şık, konu, kösnüllük, düzenleyim, sahneleme, eğreti vb. açılardan incelenmiştir.

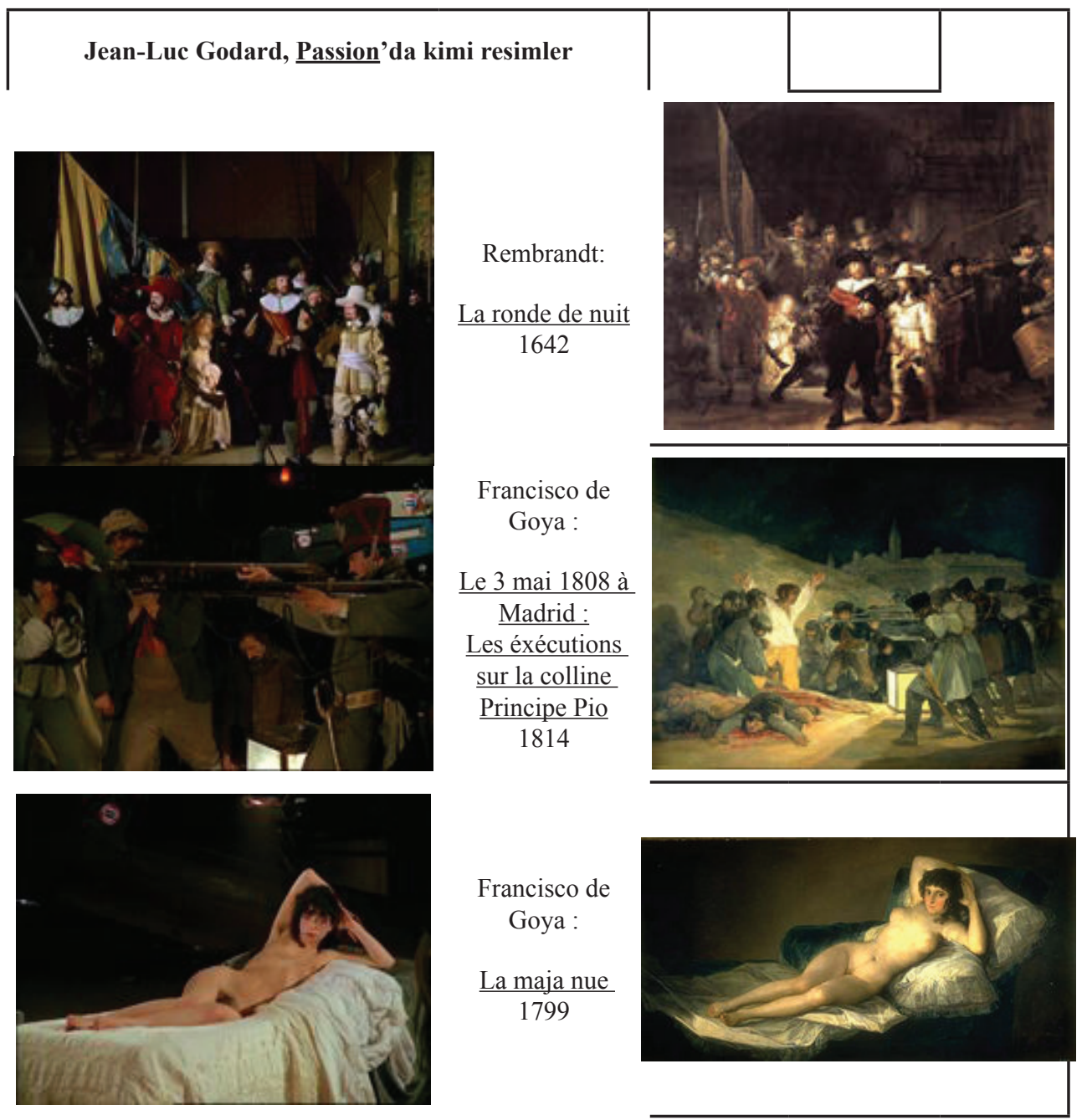




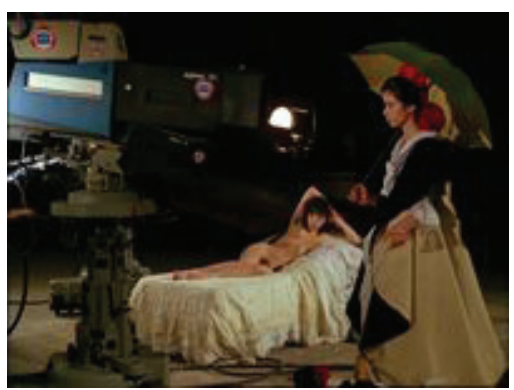

Francisco de Goya :

Le parasol 1777
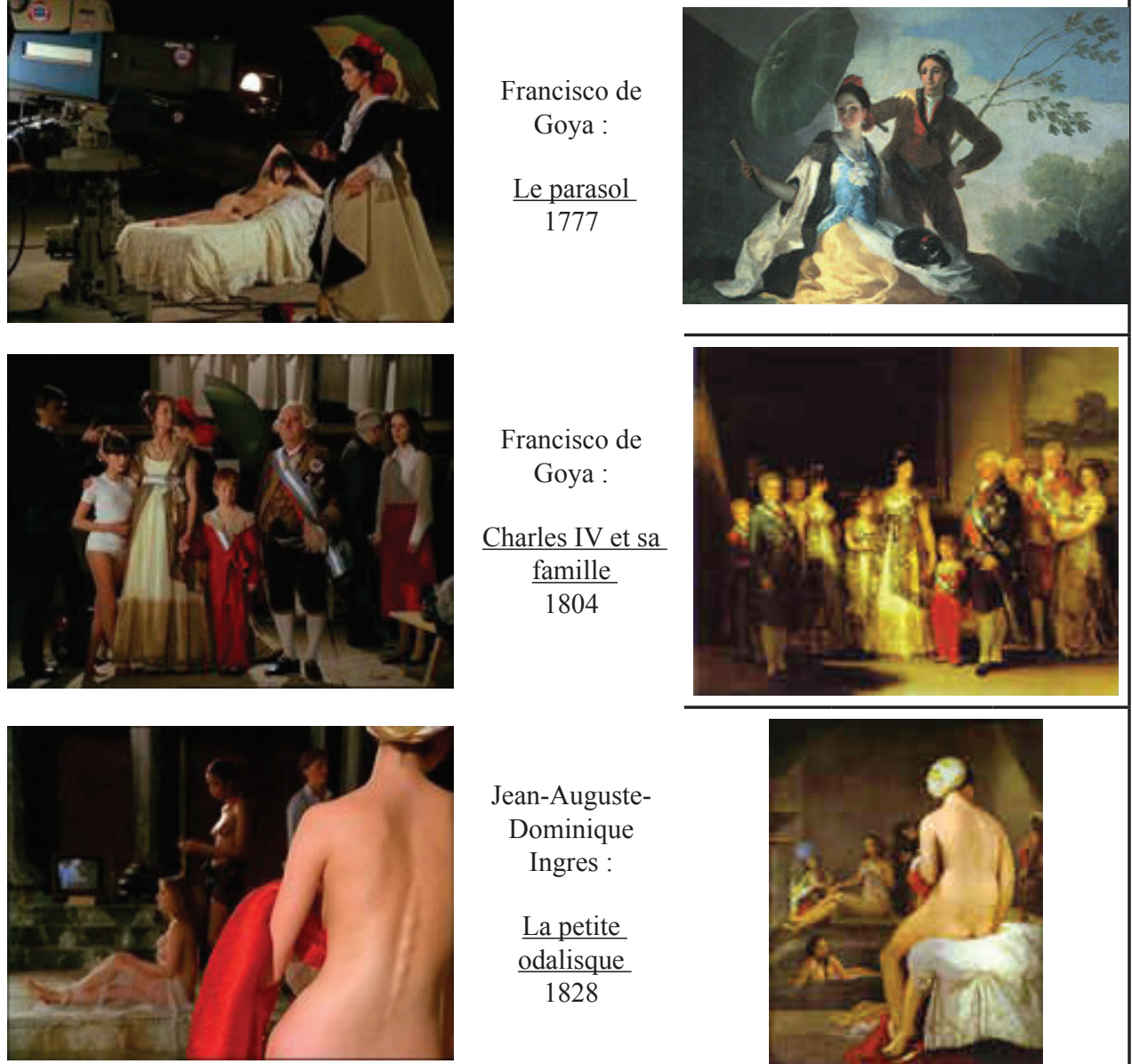

Jean-Auguste-

Dominique

Ingres :

$\underline{\text { La petite }}$ odalisque

1828
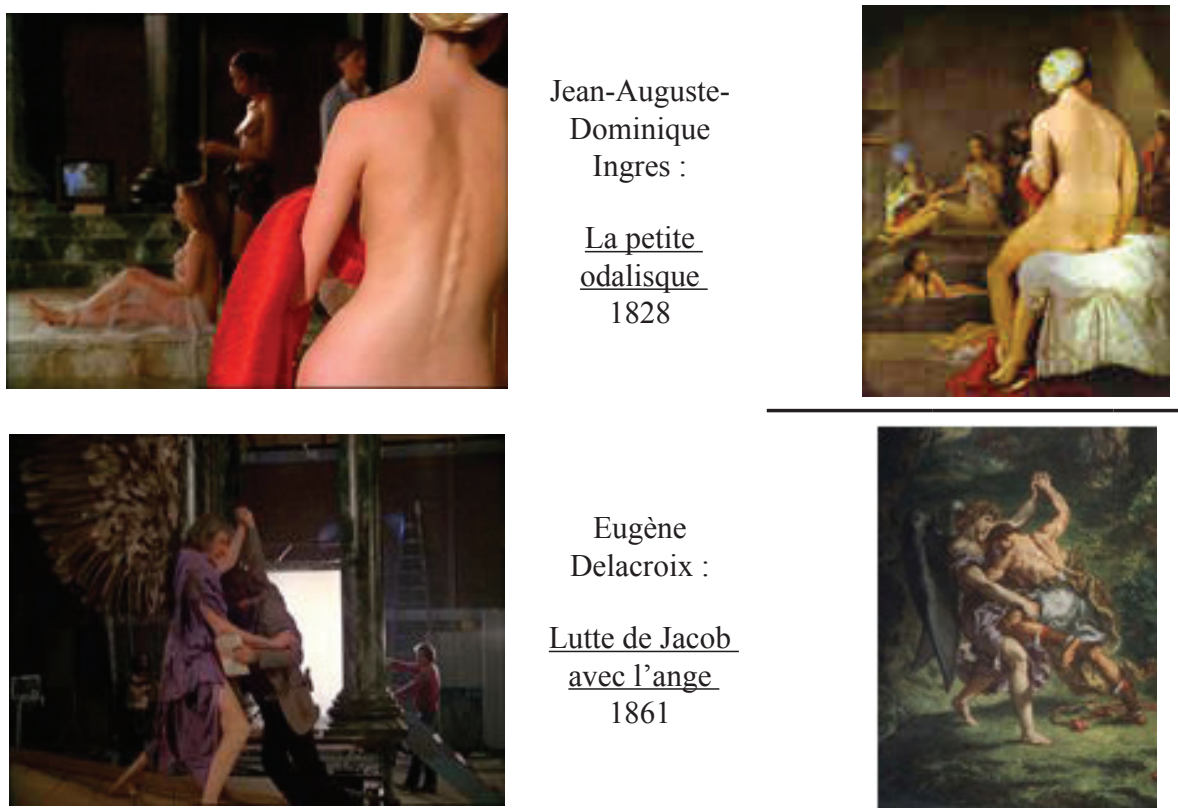

Eugène

Delacroix :

$\underline{\text { Lutte de Jacob }}$ avec l'ange 1861

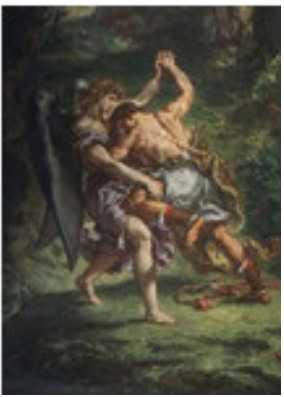




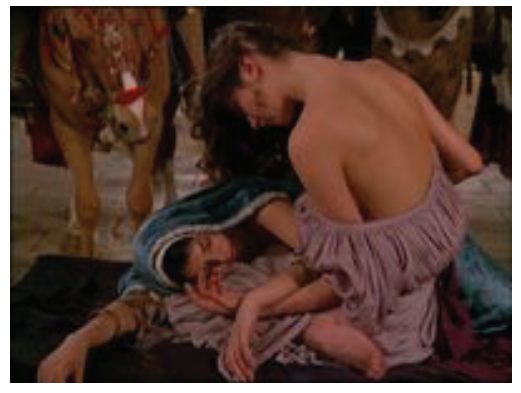

Eugène

Delacroix :

Entrée des croisés dans Constantinople 1840
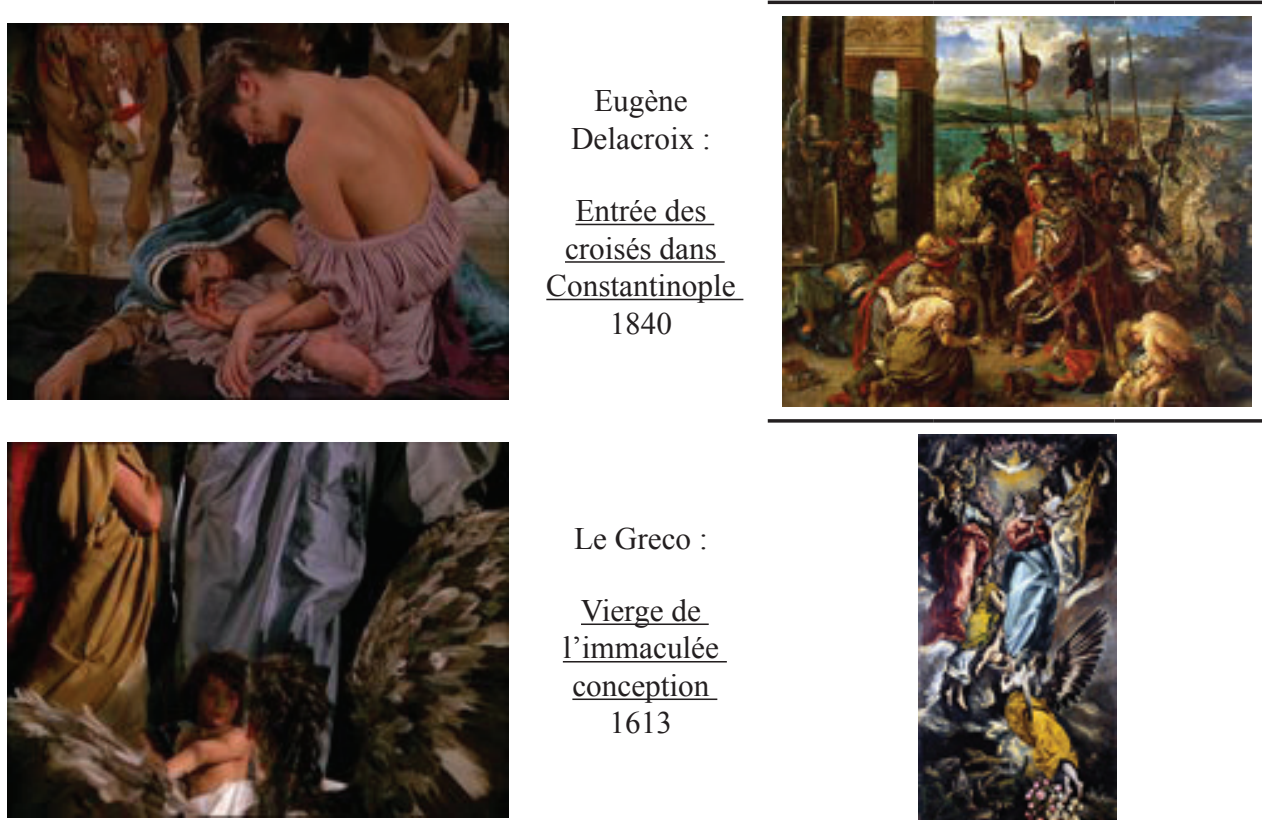

Le Greco :

Vierge de

l'immaculée conception 1613
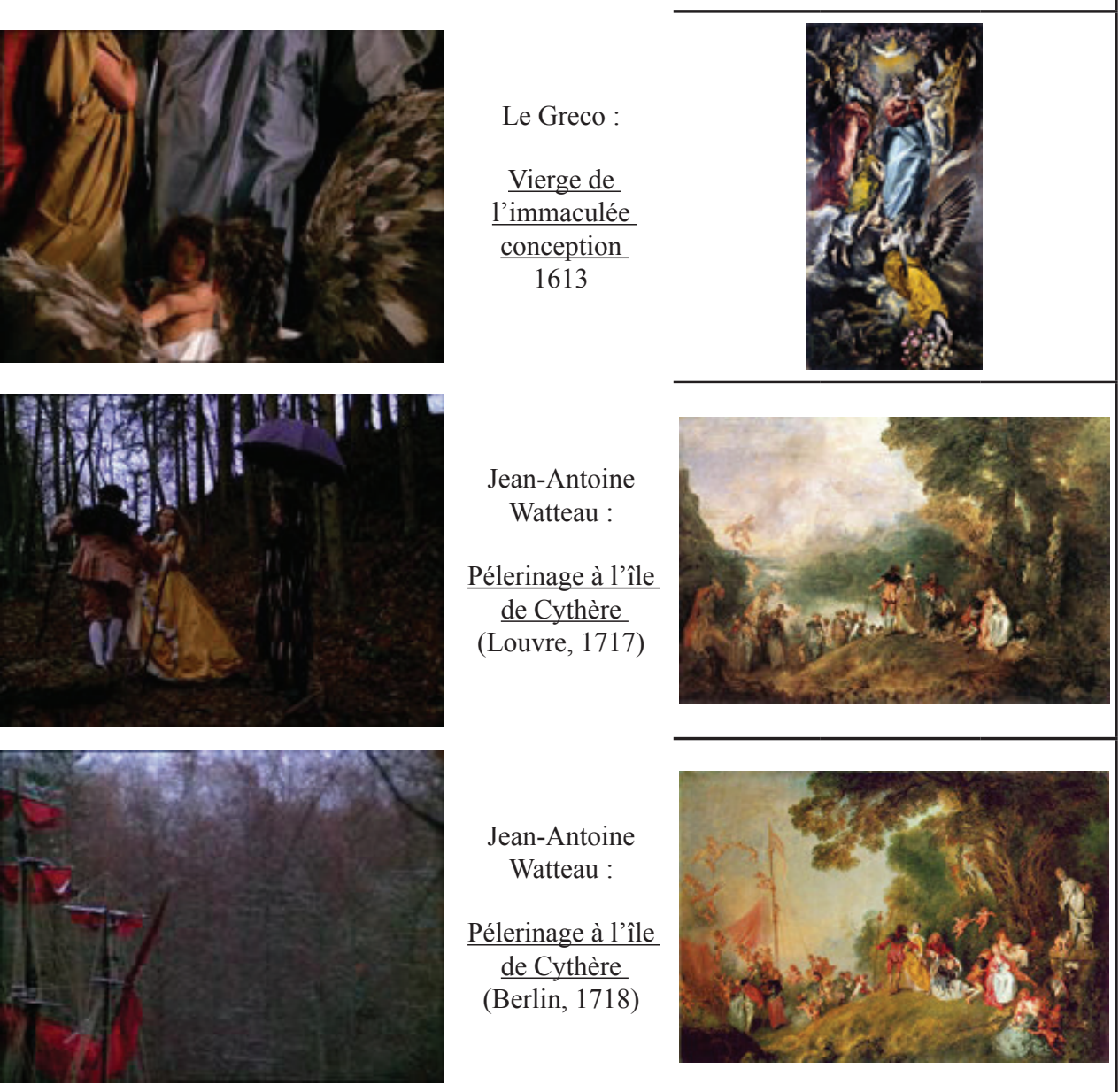

\section{Jean-Antoine
Watteau :
Pélerinage à l'île
de Cythère
(Louvre, 1717) \\ Jean-Antoine
Watteau :
Pélerinage à l'île
de Cythère
(Louvre, 1717) \\ Jean-Antoine
Watteau :
$\frac{\text { Pélerinage à l'île }}{\text { de Cythère }}$
(Louvre, 1717) \\ Jean-Antoine
Watteau :
Pélerinage à l'île
de Cythère
(Louvre, 1717) \\ Jean-Antoine
Watteau :
Pélerinage à l'île
de Cythère
(Louvre, 1717)}

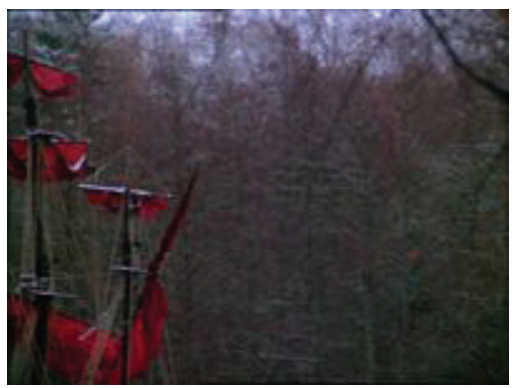

\section{Jean-Antoine}

Watteau :

Pélerinage à l'île de Cythère (Berlin, 1718)

Passion, sanat tarihinin büyük sanatçılarının resimlerinin yan yana getirildiği bir resim galerisi gibidir. Filmde, Delacroix, Caravaggio, Goya, Rembrandt gibi ressamların en bilinen resimleri bazen birebir, bazense yalın bir gönderme olarak, canlı sahneler biçiminde canlandırılır. Passion'da karşımıza çıkan resimler şunlardır: Rembrandt: La Ronde de nuit (Gece Devriyesi, 1642); Francisco de Goya: Le 3 Mai 1808 à Madrid (3 Mayıs 1808, Madrid, 1814); La Maja Nue (Çıplak Maya, 1799); Le Parasol (Şemsiye, 1777); Charles IV et Sa 
Famille (IV. Charles ve Ailesi, 1804); Jean-Auguste-Dominique Ingres: La Petite Odalisque (Küçük Odalık, 1828); Eugène Delacroix: Lutte de Jacob avec l'Ange (Yakup'un Melekle Savaş1, 1861); Entrée des Croisés dans Constantinople, (Haçlıların İstanbul'a Girişi, 1840); El Greco: Vierge de l'Immaculée Conception (Meryem'in Günahsız Gebeliği, 1613); JeanAntoine Watteau: Pélerinage dans l'île de Cythère (Çuha Adasina Yolculuk, 1717).

Passion, bir film içinde film $^{33}$ tanımına uygun düşmektedir. Filmde, Jerzy (Godard'ın ikizi) aracılığıyla hem bir film çekme süreci konu edilir hem de Isabelle'in "hikâyesi" anlatılır. İki öykü koşut gelişir. Bu öykülerin içerikleri nelerdir? Kısaca özetleyelim.

Bir yönetmen olan Jerzy, Passion adında bir film çekmeye uğraşır. Herkes filmin "hikâyesini" merak eder. "Bu filmin hikâyesi nedir?" sorusu karşısında Jerzy, 1srarla filmin hikâyesinin olmadığını/olmayacağını belirtir. Çekim sırasında türlü güçlükler yaşar. Örneğin, kendisine verilen bütçeyi fazlasıyla aşar. Filmin yapımcılarından birisi filmin tamamlanabilmesi amacıyla para bulmaya uğraşır. Avrupa'daki son umut olan İtalya'dan para bulunamayınca, Jerzy’nin karşı çıkmasına karşın, yapımcılar yüzlerini Amerika’ya (Hollywood'a) çevirirler.

Isabelle ise, bir fabrikada işçi olarak çalışmaktadır. İşinden kovulur. Tüm çabası ya tazminatını almak ya da işe geri dönmektir. Isabelle'inki bir 'hak' mücadelesidir. Isabelle' in hikâyesiyle J.L. Godard, yeni bir sinema dili yaratmak arayışından başka siyasal bir eğilim içerisinde olur; Marksist bir tutum izler.

Jerzy'nin (J.L. Godard'ın) söylediği gibi, filmin bir hikâyesinin olmaması ne anlama gelmektedir? Passion, modern anlatının izinden gidiyor gibidir. Kurgunun alanında Joseph Conrad, James Joyce ve Marcel Proust, sinemada ise Alain Resnais ve Ingmar Bergman gibi J. L. Godard, bir hikâye anlatmanın kolay olmadığına inanır. Ona göre kolay hikâye yoktur. Çünkü modern dünya alabildiğine karışık ve kaotiktir. Öyleyse gerçeği tamlığı içerisinde kavramak alabildiğine güçtür. Anlatı, insan ve dünya konusunda ancak sınırlı bir bilgi aktarabilir. J. L. Godard'ın filmlerinde kopuk bir yapının göze çarpmasının nedeni yanında Jerzy’nin çevirdiği bir filmin hikâyesinin olmadığını ileri sürmesinin örtük anlamı budur.

İzleksel bakımdan, Isabelle'in hikâyesi, J.L. Godard'ın filmlerinde dile getirdiği bir hikâyenin yinelenmesidir: patronların işçi sınıfını sömürmesi. Isabelle, niteliği hiçe sayıp üretimden yana çıkan bir anlayışa karşı çıktığı için işten atılır. O, filmdeki törel yanı temsil eder. Jerzy'nin yardımcısı Sophie'ye şu soruyu sorar: Neden filmler hiçbir zaman işçileri çalışırken göstermezler? J.L. Godard, bu soruyla aynı zamanda sinema endüstrisine eleştirisini yöneltir. İnsan yaşamını belirleyen ekonomik gerçeklikleri görmezden gelerek sinemanın sırf bir eğlendirme aracı durumuna getirilmesi çabasını yerer.

J. L. Godard, söz konusu iki ayrı hikâyeyi canlı resimler aracılığıyla buluşturur. Bu yolla filmde giysiler, yüzler, jestler ayrıntılı bir biçimde betimlenir. Resimler, film içinde dekoratif birer unsur olarak yer almaz, aksiyonun anlaşılmasına katkı sağlarlar. Örneğin canlandırılan kimi resimler Isabelle'in hikâyesine 1şık tutarlar.

Filmin başlarında Isabelle, işinin başında gösterilirken Rembrandt'ın Gece Devriyesi adlı resmi görülür. Isabelle'i gösteren planlar ve resim almaşır. Kamera, kişilerin yüzlerini 
yakın çekim yapar. Bir ses şunları söyler: "Çekimlerin yapısına bakmayın, Rembrandt gibi yapın, insanları uzunca bir süre inceleyin, dudaklarına gözlerine bakın.” J. L. Godard, Isabelle'in, Rembrandt'ın resmindeki gibi, ayrıntılı bir portresini çizer, kişiliğini aydınlatır. İşçileri çalışırken göstermeyen filmlerin tersine onun görüntüsünün Gece Devriyesi'ndeki burjuva kişiler gibi açıklıkla resmedilmeye layık olduğunu düşünür.

Filmde Goya'nın kimi resimleri de canlı resim olarak yinelenir. 3 Mayıs 1808 bunlardan birisidir. Resimde, köylülerin Fransız askerlerince kurşuna dizilmesi sahnesi anlatılır. Bu görüntü üzerinden, kamera güçlüler karşısında güçsüzlerin dramatik durumunu kaydeder. Ölmeyi bekleyen insanların can çekişmeleri üzerine odaklanılır. Bu sahneden önce Isabelle'in evinde toplanan işçiler, bir işçi sendikası kurmak üzerine tartışırlar. Kamera, bu kez kadınların yüzlerini gösterir. Hep birlikte mücadele etmeye karar verirler. Kamera çekimi 3 Mayıs 1808 ile kesilir. İşini severek yapmak uğraşında olan, sömürülmek istemeyen kadınlar patrona görüşlerini bildirirler. Sonunda Isabelle, ötekiler gibi, işini kaybeder. O ve ötekiler, Goya'nın resmindeki çaresiz, güçsüz köylüler gibidirler. Goya'nın alıntılanan ve yeniden canlandırılan resimleri Isabelle'in başkaldırısının metaforik anlatımı olurlar.

J. L. Godard, El Greco'nun l'Immaculée Conception (Lekesiz Gebelik, 1611) adlı resmini yinelerken yine Isabelle üzerinde yoğunlaşır. Isabelle ile El Greco'nun resmindeki Vierge Marie (Bakire Meryem) görüntüleri özdeş konuma getirilir. Benzerlikleri açıktır. Isabelle, Agnus Dei 'yi ${ }^{34}$ okur. İşini dürüstçe yapmak isteyen, sömürülmek istemeyen, sonunda işinden olan Isabelle'in yaşadığı acılar bu kez dinsel bir boyuta taşınır; durumu El Greco'nun resminde Bakire Meryem'in çektiği acılarla özdeşleştirilir.

Canlı resimler biçiminde yinelenen eski resimleri yalnızca Isabelle'in hikâyesine indirgemek eksik olacaktır. Canlı resimler, Jerzy’nin çekmeyi başaramadığ 1 filmde değişik işlevler yüklenir, birer metafor olarak kullanılır, J.L. Godard'ın resim ve sinema ilişkilerine bakışı, resmin filme yapısal bakımdan getirisi konusunda vb. kimi ipuçları verirler.

Rembrandt'ın resmi 1şık sorunu üzerine odaklanır. Filmde, Jerzy sürekli olarak ışığın yetersizliğinden yakınır. Sahne, ışığın yetersizliği ve yönü üzerinde yoğunlaşır. Söz konusu sahne boyunca kişiler sürekli hareket ederler. Böylelikle doğru duruşu bulmaya çalıştıkları sanılır. Oysa J.L. Godard, alt-resimleri tümüyle durağan bir biçimde yinelemek istemez. Elena del Rio’ya bakılırsa, ${ }^{35}$ özgün bir resmi canlandırmaya uğraşan tüm kişileri kıpırtısız göstermekten çok J. L. Godard'ın canlı resimler biçiminde yinelediği resimler hareketli parçalar olarak duyularımızı etkiler, bedeni öne çıkarır, algı ve anlatıma zamansallık kavramını yeniden sokarlar. Resimler temsilden performansa kaydırılarak yeni, özgün, sorgulamaya açık birer olay durumuna gelirler. Kişilerin duruşları durağanlaştığı anda, fabrika sahnesi araya girer. Durağanlık resme, hareket sinemaya göndermedir. J. L. Godard, her iki sanatsal biçim arasındaki en temel ayrımı böyle bir kullanımla özetler. Kendince kimi kamera oyunlarına başvurarak Rembrandt'ın resmini dönüştürür. Örneğin, Rembrandt'ın resmini olduğu gibi göstermek yerine Hollanda resminde tipik bir kullanım olan yukarıdan aşağıya ya da geniş planlarla kişiler gösterilir. Bu yöntemle bir bakıma sinemasal bir çerçeveleme işlemi gerçekleştirilir. Kişilerin bedenleri aynı biçimde gösterilir. 
J. L. Godard, ışığın yönünü değiştirerek resme canlılık katar. Resmin büyük bölümü ise karanlıkta kalır. Kimi zaman, bir anda sağdan, soldan, yukarıdan, aşağıdan gelen 1şık kişileri aydınlatır. Jerzy’nin amacı doğru ışığı bulmaktır (filmde ışığın ayrıca dinsel bir yan anlamı var).

J. L. Godard, Rembrandt'ın açık-koyu renk kullanımını anımsatır biçimde 1 şığı kullanır. Işığın değişmesi sahneleri Rembrandt'ın, kimi resimlerinde duruma göre 1şığı değiştirmesi biçimine bir göndermedir. Rembrandt, 1şık oyunlarıyla yeni olanı arar. Filmde, 1şık ve gölge oyunlarıyla coşku ve görüntüde derinlik yaratmak ister.

Iş1k ve gölgeye asıl değerini veren Rembrandt olmuştur. Bu nedenle yönetmenler ve kameramanlar için Rembrandt ideal bir resimsel örnekçe olmuştur. Örneğin, 1910 yılında yönetmen Cecile B. DeMille bir "Rembrandt 1şı̆̆ından"36 bile söz eder. J.L. Godard'ın 1980’li yıllarda çevirdiği filmlerde 1şığa olan ilgisi dinsel konulara olan ilgisiyle iç içedir. Bu dönemde J.L. Godard, ışığa tinsel bir anlam yüklenen dinsel gelenekten, ayrıca 1şık metaforu ile kimi zaman “Tanrı’nın inayeti” (kurtarıcı kişisi) olarak görülen, “insanların ışıktan beslenmemelerinden" yakınan Simone Weil'den etkilenir. ${ }^{37}$ J. L. Godard için $1 s ̧ 1 k$, saf bir enerji, tinsel bir besindir. Passion'da kişileri, 1şığa gereksinimi olan kişiler olarak betimler. S. Weil'in kişilik özellikleri Isabelle'den yansır.

J. L. Godard'ın Passion'dan başka Je vous salue, Marie (1985), Nouvelle Vague (1990) ve Histoire (s) du cinéma'da (1989-98) dinsel verileri daha fazla kullandığını anımsatalım. Yönetmen, söz konusu filmlerde İncil'e yaslanır. Bu filmler dinsel sorunları odağa alan yapıtlar olarak görülürler. J. L. Godard, İsa'nın çarmıha gerilişi, öldükten sonra dirilişi vb. konulara ilgi duyar. Dinsel içeriklere sıklıkla yer veren filmler birer mesel gibidirler; materyalizmin tinsel bakımdan iflasını anlatırlar. J. L. Godard, Passion'da İsa'nın yaşamöyküsüne gönderme yaparak tinselliğe döner. Filmin başlığı eski ikonografik bir geleneğe göndermedir. J. L. Godard, filmde hem bir yaratım sürecine gönderme yapar (yaratmak bir bakıma "çile" çekmektir) hem de günlük olaylar, siyaset, sanat, estetik arasındaki ayrım üzerinde durur. Film, aynı zamanda görüntü üzerinedir. Hıristiyanlıkta görüntü anlayışı J. L. Godard'ın ilgisini çeker. Hıristiyanlığın görüntüye bakışı üzerinde odaklanır.

J. L. Godard'ın film anlayışı, gerçekliğin tanrısal bir varlığın gösterimi olduğuna inanan A. Bazin'in Hıristiyanlığın hümanist ve varoluşçu öğretisinden etkilenir. J. L. Godard, A. Bazin gibi, sinemanın iyileştirici, kurtarıcı etkisi olduğuna inanır. Bu nedenle sinemadan sıklıkla dinsel metaforlar aracılığıyla söz eder. Örneğin, sinema ekranını Azize Veronica'nın bezine $^{38}$ ya da Merhametli Samaritaine'in kefenine benzetir. ${ }^{39}$ Görüntüyü "kurtuluş" (rédemption) olarak niteler. J. L. Godard için sinema, dinsel bir edim, bir inanış biçimidir (Hıristiyanlık gibi sinema da kanlı bir tarihe dayanmaz). Ona göre, XX. yüzyılda yaşanan korkunç olaylara ancak sinema ile yanıt verilebilir. Sinemanın, görüntünün kurtarıcı bir işlevi vardır. Beyaz bir ekran üzerinde birden bire mucizevi bir biçimde beliren görüntüler ressamların boş tuvallerine benzer. Passion'un senaryosunu yazmak istemeyen J. L. Godard yine İncil'e gönderme yapar: “Acaba Musa kendisine gönderilen yasaları okudu mu yoksa tabletler üzerinde gördü mü?” (Jacobs, 2012:110) sorusunu sorar. Önce dünyayı görür, 
sonra yazarsınız. Öyleyse Passion'da dünyayı filme alırken önce, böyle bir dünyanın olup olmadığını görmek gerekir. Önceliği görmeye vermek, dünyayı daha fazla görmek, J.L. Godard'ın film üretme sürecinin bir özeti gibidir.

Dinsel izlekler El Greco'nun l'Immaculée Conception'unda yinelenir. Dinsel bir göndermeyi içeren filmin başlığ 1 (Çile) ile film çevirmenin güçlüğü vurgulanır. Söz konusu güçlük o denli fazladır ki yönetmen bir bakıma İsa'nın çektiği acıları çeker.

Jerzy'nin bir canlı resim biçiminde alıntıladığı Delacroix’nın la Prise de Constantinople par les croisés'si (İstanbul'un Haçlılar Tarafından Alınması, 1840) dinsellikten uzaklaşarak profan kategorisine yaklaşır. Resmi, bir resim ve sinema ilişkisi çerçevesinde değerlendirmek gerekir.

J. L. Godard'ın Delacroix'nin resmini alıntılaması boşuna değildir. Jerzy aracılı̆̆ıyla filmde bir yönetmenin çalışma biçimi canlandırılır. Bu açıdan tuvali önünde resim yaparken görünmekten kaçınmayan Delacroix ile benzeşir. Delacroix, tuvalinde bıraktığı fırça izlerini bile gösterir.

Delacroix'nın resminde kişiler bitkin, yorgun bir durumda gösterilirler. Bedenleri ağırlaşmış, savaş onlarda bezginlik yaratmıştır. Bir yas havası sezilir. Passion'da canlandırılmak istenen bu içeriktir.

J. L. Godard'ın, eski resimleri canlandırırken amacı onlara saygısını bildirmek değildir. Eski resimlerin arkasındaki kültürel boyutu kavramak, bitmiş, tamamlanmış, müzeye kapatılmaya hazır duruma gelmiş bir resmi olduğu gibi aktarmak arayışında olmaz. Çabası, resmin estetik bakımdan değerini, ağırlığını anlamaktır. Dolayısıyla sinema ekranı yalnızca bir çerçeve değildir, bir şey gizleyen, ekrandan yansıyan kişinin daha sonra da yaşamasına olanak sağlayan şeydir. Söylediğimiz gibi, Jerzy, resimdeki görüntüleri yinelemek ister ancak başarısız olur. Onun aracılığıyla, canlandırmak isterken sanatçının (ve resmin) toplumsal ve çalışma koşuluna ilişkin ipuçları verilir. Sanat güç bir uğraştır. Delacroix’nın resminin seçilmesinin nedeni budur. Tarihsel bir olayı resmederek sahnelemek nasıl güçse sinemada bir sahneyi canlandırmak o denli güçtür.

Resmi canlandırırken J. L. Godard'ın bir diğer amacı filmin çabucak unutulmasının önüne geçmektir. Görüntülerin alınıp satıldı̆̆ı, bir pazar nesnesi durumuna getirildiği bir dünyada J. L. Godard'ın kaygısı böylelikle daha iyi anlaşılmaktadır. Sıradan Hollywood tarzı bir film çekmek, yapay bir gerçeklik etkisi yaratmak arayışında değildir. Passion, ideolojik sorunların öne alındığı sinema anlayışında çok daha ileri giderek görüntülerin doygunluğa ulaştığı, bir görüntünün altında başka bir görüntünün gizli olduğu bir dönemde yanılsamaya düşmeden gerçekliğin nasıl yansıtılabileceğini tartışır. Gerçekliğin alabildiğine gerçekdışılaştığı bir dünyada, Delacroix’nın resmini alıntılayarak, J. L. Godard, görüntünün, dolayısıyla sanatın bir yorumdan başka bir şey olmadığını da göstermek ister. Ona göre sanat sürekli olarak birbirine gönderen bir döngüsellik içerisine girmiştir. Bu yaklaşım, postmodern kuramcıların metinlerarasılık çerçevesinde yaptıkları tanımlamalarla örtüşür. Sanat, durmadan yeniden başlar, temsilin sonu yoktur: "Temsil, her zaman önceden başladığından sonu yoktur. Temsilin kapandığını düşünmek trajiği düşünmektir: yazgının 
temsili olarak değil, temsilin yazgısı olarak"40 dünyayı bir gerçeklik mantığı üzerine oturtmak olanaksızdır. Gerçeklik bir yanılsamadan başka bir şey değildir. Gerçeklik sonsuz yoruma açık bir duruma gelmiştir. Öyleyse sinema gerçekliği olduğu gibi yakalamakla uğraşmaz, gerçekliğin ele geçirilemez yanını kavrayabilmenin koşulu yapay olandır. Guy Scarpetta'nın söylediği gibi, "genelleştirilmiş bir görünüş estetiği”" vardır. ${ }^{41}$ Passion' da temsil sürecini izleyicinin tamamlanması beklenir. Anlam, izleyicinin bakışı, katılımıyla belirir. Kalıplaşmış bir anlam söz konusu olamaz. Marcel Duchamp'ın söylediği gibi, “Resmi yapanlar resme bakanlardır."

J. L. Godard, resim ve sinemayı buluşturken resme yeni unsurlar, örneğin ses ekler. Konuşmaların, iç konuşmaların sayısını çoğaltır. Bunlara müzik eklenir. Kimi zaman sessiz anlar yer alır, kimi tümceleri anlamlandırmak ise pek olası görünmemektedir. Bütün parçalanır. J. L. Godard'ın yaklaşımı Nietzsche'nin “yaşam kopuk anların ardışıklığıyla oluşur" tanımına benzer. ${ }^{43}$ Bütünlüğü parçalamak, karıştırmak, kişinin geleneksel yapılardan uzaklaşması, sanata yeni bir anlayış getirme çabasıdır (ancak Passion'da bu arayış başarısızlıkla sonuçlanır). Canlı resimlerin bütünlüğü kameranın yer değiştirmeleriyle parçalanır, ışığın yönüyle oynanması, kişilerin kıpırdamadan durmayı başaramamaları diğer parçalanma figürleridir. Pascal Bonitzer, (1985:68) ${ }^{44}$ Passion' da filmsel görüntü ile resimsel görüntü arasında bir çatışma olduğundan söz eder. J. L. Godard, planlarla, uzamla da oynar, uzamı parçalar. Boş uzamlar, parçalı bedenler, alışılmadık açılar yaratır, objektifi aniden başka yöne çevirir. Böylelikle bütünlük anlayışını yıkar. Öznenin nesneye bakış biçimini sorunsallaştırır.

Kısacası J. L. Godard'ın amacı eski resimleri bağlamlarından çekip alarak olduğu gibi yinelemek değildir. Onları biçimsel ve anlamsal dönüşümlere uğratır. Filmin konusu eski resimler de değildir. J.L. Godard, eskiyi sinemanın gereçleriyle yeniden kurgulayarak yeni bir dil yaratır. Farklı dönemlerden, farklı biçemlerden, kültürlerden resimleri yan yana getirerek, daha önce söylediğimiz gibi, Histoire(s) du cinéma'da Malraux'nun düşsel bir müze ${ }^{45}$ yaratma çabasına uygun davranır. Ona göre, görüntülerin, videonun, yeni teknolojilerin yaygınlaştı̆̆g bir düzende sinema yok olma tehlikesiyle yüz yüzedir.

Passion, eskiye bir dönüş olduğu kadar, eskinin yeni koşullardaki alımlanmasına, sinemada yaratıcı sürece, ayrı sanatsal biçimlerin buluşturulmasıyla karşılaşılan sorunlara ilişkin konuları gündeme taşır.

W. Moser, Passion'un konusunun bir resimden yola çıkarak bir film çekmenin güçlüğü üzerine olduğuna vurgu yapar:

"Godard, ne resimsel bir üretim ya da yaratımı ne de resmin medyatik üretim koşullarını göstermektedir, onun gösterdiği sinemasal üretimdir. Hiçbir zaman bizi bir ressamın atölyesinde gezdirmez. Hiçbir zaman resmetme edimini göstermez, hiçbir zaman - filmsel bir ekfrasis modunda - bir resmi filme almaz. Bizi daha çok bir sinema stüdyosuna sokar, bize kostümlü figüranlar aracılığıla büyün yapıtları birer canlı resimler biçiminde gösterir. Bu yeniden canlandırma sürecini filme alır ve istisnai olarak, sonucunu filme alır." ${ }^{\prime 46}$ 
J. L. Godard, "film ve resim arasındaki sanatlararası ilişkiyi filmin medyasallığını göstermek için" kullanır. ${ }^{47}$ Sinemanın atası sayılan resim, yönetmenin temel bir örnekçesi olur, ona esin kaynağı olur. "Eski bir medya yeni bir konfigürasyona sokulur."

W. Moser, J. L. Godard'ın, filmde bir canlı resim biçiminde yer verdiği Goya'nın Le 3 Mai 1808'inin (3 Mayıs 1808) yeni bağlamda uğradığ1 dönüşümler üzerinde durur. Örneğin, kamera klasik müzik eşliğinde kompozisyonun odağına yöneltilir; travelling yapan bir diğer kamera gösterilir. Böylelikle resmin iki boyutluluğuna üçüncü bir boyut eklenir. J.L. Godard, bu yolla bakış açısı yanında resmin siyasal anlamını değiştirir. Jerzy'nin "gözlemliyorum, dönüştürüyorum, aktarlyorum” demesinin nedeni budur. Eski resimleri canlandırarak, filme alarak yeniden üretme işlemini doğrular ve üstlenir (Bu yaklaşım metinlerarasılığın, yenidenyazmanın doğasına uygundur). W. Moser'a göre, resim ve sinema arasındaki sanatlararası ilişkiye başvurarak J.L. Godard, filmin medyasal özelliğini göstermek ister. J.L. Godard'ın filmi aynı zamanda Hollywood sinemasına bir karşı çıkıştır. Jerzy'nin filmi bitirmemesinin nedeni onun çabucak unutulacak bir tüketim nesnesine dönüşmesinin önüne geçmektir.

Passion ile J. L. Godard'ın çabası sanki "sinemasal bir deneme" ortaya koymaktır: "Kendimi bir denemeci olarak görüyorum. Roman biçiminde denemeler, ya da deneme biçiminde romanlar yapıyorum: yalnızca onları yazmak yerine filme alıyorum." içeriğin düzenleyimi, alıntılanan resimlerin birer canlı resimler biçiminde ve bir tür kolaj (kolaj, ayrışık unsurların yeni bir bütüne katılımıdır) işlemiyle kullanımı filme deneme özelliği katar. Denemeyi belirleyen, klasik metnin yazım kuralları karşısında özgürce hareket etmektir. J. L. Godard'ın Passion için bir senaryo yazmaması, filmin akışını rastlantıya bırakması, film çekiminin aşamalarıyla istediği gibi oynaması, akışı değiştirmesi bu tanımlamaya uygun düşer.

Yine de J .L. Godard'in filmi tam olarak ne bir türe ne de özel bir kavramsal ya da söylemsel alana bağlanabilir. Film, karma bir yapıdadır. Orada resmin verileri çokça kullanılır, iki ayrışık unsur tek bir yerde buluşturulur, resimle film kaynaştırılır. Böylelikle yeni, alışılmamış, bilinenden ayrı bir dil, ayrışık, dolayısıyla çokbiçimli (ve çokanlamlı) bir yapı yaratılır. J.L. Godard'da kurgudan belgesele, filmden videoya, kuramsal düşünceden şiire, görüntüden metne geçiş bildik bir uygulamadır.

J. L. Godard, kolaj kullanımına da başvurur. Eski bir yazıda, Geneviève Mouillaud şunları söyler: “Godard'ın filmlerindeki parçalar ve bölümler önceden yapılmış, tanınabilir, ancak belli bir düzene göre yan yana getirilmiş, birbirlerine yapıştırılmış nesnelerdir. Nesnenin her türünü bulabilirsiniz: reklam resimleri, kart postallar, afişler, film içinde film parçaları; başlıklarını hatta kimi sayfalarını okuyabileceğiniz kitaplar; alt-başlıklar, yazılı lejandlar; konuşma dilinden yapılan çok sayıda alıntılar; Yüksek Kültürün tam bir panayırı; günlük folklordan kesitler (...)”(Mouillaud,1965: 116). Bu listeye çok sayıda resim eklenir.

J. L. Godard'ın filmlerindeki sürekli bir doğaçlama eğilimi, bir yaptakçı doğallığının izlerini taşır. Aslında filmin düzenleyiminde kullanıma sokulan parçaların düzeni konusunda herhangi bir ilkeye bağlanılmaz. G. Mouillaud'nun söylediği gibi, “bu, yaptakçılığın kendi 
iç yasaları var, tam olarak bir kopukluk izlenimi veren yasalardan birisi söz konusudur: Her parça bağlamına uyumsuz bir ilişkiyle bağlanıyor, o denli ki sorunsuz bir katılımı olanaksız k1liyor" (Moulliaud, 1965: 116).

Tek bir ilke çevresinde odaklanmayan, aşamalanma düşüncesini sarsan, almaşımlarla işleyen, kopukluk etkisi yaratan filmde olaylar eşsüremli bir biçimde gelişir. Gilles Deleuze, Logique du Sens'da (Anlamın Mantığı, 1969) bir deneme olarak sinemadan "olayların eşsüremliliği” olarak söz eder. (Deleuze, 1969: 303). Her unsur, ayrıntı, sahne, resim, görüntü vd. ötekinden ayrıdır. Bir öykü, bir düşünce tamlığı içinde aktarılmaz. Filmin sonunda her unsurun kendi yerini bulacağı beklentisi vardır. Her izleyici, her alıcı kendince ondan bir şeyler çıkarır. Çevrilen filme dâhil edilir. Düşünsel ve sanatsal bakımdan anlam üretimine katılması beklenir. Böyle bir tanımlama postmodernistlerin beklentilerine oldukça uygun düşmektedir. Yönetmen, düşüncesini açıç̧a bildirmez. Bizi düşünsel, sanatsal deneyimine katar. Yapıtından olabildikçe fazla anlamlar çıkarmaya çağırır. Önümüze koyduğu deneysel bir üründür. Bir şey anlatmaktan, bir düşünceye inandırmaktan, bir düşünceyi açıklamaktan çok alıcıyı sözlerden, görüntülerden bir düşünce, fikir üretmeye zorlar.

Belli bir kurala göre eklemlenmeyen filmsel unsurlar nedeniyle tüm filmden kesin anlamlar çıkarmak olası değildir. Çıkarılan, kişiye ve duruma göre anlam parçalarıdır. Uzlaştırılamayan tüm unsurlar tek bir bedenle uzlaşırlar. Roland Barthes'ın tanımladığı gibi, beden bir "montaj” işlevi yüklenir. Metnin Tadı adlı kitabındaki bir benzetmeyi yinelersek, "metin insansal bir biçime bürünebilir." Ya da metin "bedenin bir figürü, onun bir anagramıdır.” (Barthes, 1973: 30). Beden figürleşir. J. L. Godard'ın Scénario du film Passion'unda (Çile'nin film senaryosu) yüz, eller birer figür, hareketli görüntüler biçiminde kullanılır; filmde söylemin ayrılmaz bir parçası olurlar. "Her beden bir alıntı, önceden yazılmış bir metindir. Arzunun kökeni heykeldir, resimdir, görüntüdür” (Barthes, 1970: 40). J.L. Godard, Passion'da ve Scénario du film Passion'da kendi bedeni yanında alıntıladığ1 başka bedenlerin arayışına çıkar. Onları birer gösterge, belirtge olarak kullanır. Her biri imleyen birer alıntıdır. Onları bağlamlarından koparıp yeni anlam alanı yaratmak amacıyla yeni bir bağlama taşır. Film, yeni görüntülerle (resimlerle) çoğullaşır, karnavallaşır. Sürekli bir arayış peşinde koşulur. Üst üste konulan unsurlarla filmde hem biçimsel hem de anlamsal olarak bir açıklık estetiğinin, kısacası çoksesliliğin önünü aralanır. J. L. Godard'ın filmi bir palempsest ${ }^{50}$ imgesine oldukça uygun düşer: Arkasında resimsel izlerin dolaştığı, anlamın karmaşıklaştığı bir film söz konusudur. Passion'da bir alıntı biçiminde yinelenen canlı resimler filmin yapısına ilişkin okuma olanağı sağlarlar. Canlı resimlerin olası işlevlerinden birisi budur.

Kısacası, J. L. Godard, sinemanın bildik kurallarını ters yüz eder. Akademizme, düzgülere, kurallara, klasik formüllere, sinemanın edilgen bir eğlence aracı gibi görülmesine karşı çıkar. Onu, erki, düzeni (kapitalist düzen), pazar ekonomisini yerme aracı olarak görür. J. L. Godard, klasik filmlerdeki anlatısallık eğilimini reddeder, dili parçalar. Kopukluk, sinema estetiğinin öne çıkan bir özelliği olur. Varolan süreklilik yüzeyde görülmeyen bir sürekliliktir. J. L. Godard, görüntünün metne indirgenmesini yadsır. Kolajı ve alıntıyı sinema estetiğinin ana unsuru durumuna getirir. Filmlerinde bu kullanımlarla karma bir yapı 
yaratır: "Ben edebiyat yapan bir ressamım... Renklerle ve biçimlerle çalışırım... Bunların aralarındaki bağlara bakarım" (Aktulum, 2018: 284).

Sonuç olarak; değişik sanatsal biçimlerin aralarındaki alışverişleri okumak, çözümlemek için yöntemsel veriler sunan yapısalcılığın verileri postyapısalcılarca geliştirilerek günümüzde sıklıkla kullanılmaktadır. Kullanılmaması da olası değildir. Jean-François Lyotard'ın Postmodern Durum adlı kitabında söylediği gibi, tüm disiplinlerin birbirine karıştığı günümüz koşullarında “çoksesli" okumalar yapmak bir zorunluluk durumuna gelmiştir. Göstergelerarasılık, en az iki ayrı sanatsal dizgenin aralarındaki alışverişleri biçimsel ve anlamsal düzlemde irdelenmesine yöneliktir. Bu çalışmada kimi örnekler üzerinden, özellikle resim ve sinema ilişkisi çerçevesinde Jean-Luc Godard'ın Passion adlı filminden yola çıkarak göstergelerarasılık kavramının uygulama aşamasında verilerini kullandık. Değişik sanatsal biçimlerin biçimsel ve anlamsal bakımdan alışverişleri, uğradıkları biçimsel ve anlamsal dönüşümler göstergelerarası bir sorgulamanın başlıca amacıdır. Bu yazıda eskinin yeni bir bağlamda uğradığı kimi dönüşüm biçimlerini göstergelerarası bakış açısının varsayımları ve yöntemleriyle kısaca çözümlemeye, yöntemin işleyişine belli bir somutluk kazandırmaya çalıştık.

\section{Notlar}

1 Bu konuda bkz. P.V. Zima, Critique Littéraire et Esthétique. Les fondements esthétiques des theories de la littérature, (Harmattan, 2004). Ayrıca bkz: K. Aktulum, "Yapısalcılık", in S. Bozbeyoğlu, Yazınsal Akımlar, BilgeSu Yayıncılık, 2021. Yapısalcılık konusunda Türkçe daha geniş bilgi için bkz: Tahsin Yücel, Yapısalcılık, Can Yayınları, 2020. Yapısalcılığın en ayrıntılı tarihi konusunda bkz: François Dosse, Histoire du Structuralisme I "Le Champ du Signe", ve Histoire du Structuralisme II, le Chant du cygne, de 1967 à nos jours", La Découverte, 2012. Yapısalcılığın bilgikuramsal temelleri konusunda en ayrıntılı çalışma için bkz: Anne-Gaëlle Toutain, « MONTRER AU LINGUISTE CE QU'IL FAIT» Une analyse épistémologique du structuralisme européen (Hjelmslev, Jakobson, Martinet, Benveniste) dans sa filiation saussurienne”, Université Paris-Sorbonne, 2012, 6154 sayfa.

2 Ferdinand de Saussure, Genel Dilbilim Dersleri, çev. B. Vardar, Multilingual, 2001.

3 Kuşkusuz kendi perspektifimize uygun olarak sanatı estetik düzlemde en etkili biçimde tanımlayanların başında Dominique Chateau'nun çalışmalarını önemle anmak gerekir. Örneğin bkz: Sémiotique et esthétique de l'image, l'Harmattan, 2007; la Philosophie de l'Art, fondation et fondements, 1'Harmattan, 2000; Epistémologie de l'esthétique, l'Harmattan, 2000.

4 "Méta-langage" konusunda bkz: Josette Rey-Debove, le Métalangage, Arman Colin, 1997.

5 Yazınsal ve sanatsal yapıtların postmodern bir perspektifte yorumlanmasına yönelik onlarca çalışma bulunmaktadir.

6 Klasik yapıt anlayışından ayrı olarak "ayrışıklık” yeni estetiğin: yazınsal ve sanatsal yapıtların baskın çıkan bir özelliğidir. Tüm metinlerarasılık/göstergelerarasılık tanımlamalarında bu noktaya vurgu yapılır. Bkz: Kubilay Aktulum, Metinlerarası İlişkiler; ya da Metinlerarasılık/Göstergelerarasılık adlı kitaplar.

7 Kendilik, en genel anlamıyla, bir şey, bir nesne ya da bir gerçekliktir, hatta felsefi anlamda bir tözdür, her zaman belirsiz bir doğaya ve özelliklere sahiptir ve görünüşe göre bir bireysellik, kimlik biçimine sahiptir ya da bütünlük içerir.

8 Göstergebilim yapısalcılığa koşut olarak böyle bir tutum benimser. Rus Biçimcileri, Çek Yapısalcıları, Fransız 
göstergebilim okulu yanlıları, örneğin C. Lévi-Strauss, J. Courtés, D. Bertrand, yazınsal bağlamda G. Genette, T. Todorov, J. Kristeva, C. Bremond vd. bunlar arasindadirlar.

9 Umberto Eco, Açık Yapıt, çev. N. Uğur Dalay, Can Yayınları, 2000

10 Bu konuda bkz: Alain Tirzi, La notion de génie dans la philosophie critique de Kant et son rapport à la modernité dans l'art, Université de Nice, 2002. Ya da Taylan Altuğ, Kant Estetiği, Payel, 1989.

11 Nicolas Bourriaud, Esthétique relationnelle, les Presses du reel, 2001.

12 A. G. Baumgarten, Esthétique, éd. de l'Herne, 1988. Ayrica bkz: 1- Herman Parret, De Baumgarten à Kant : sur la beauté, Revue philosophique de Louvain, Vol. 90, No. 87 (AOÛT 1992), pp. 317-343 (27 pages). 2- Gilda Bouchat, L'ESTHÉTIQUE DE "L'ANALOGON RATIONIS": Une introduction à la philosophie d'Alexander Gottlieb Baumgarten, evue de Théologie et de Philosophie Troisième série, Vol. 139, No. 1 (2007), pp. 1-20 (20 pages).

13 Ayrışıklık estetiğine bağlı olarak karma yapı yeni sanatsal biçimlerin ayırıcı bir özelliğidir. Bu konuda bkz: 1Emmanule Molinet, L'hybride, une problématique centrale de l'art actuel face à un monde multipolaire. De la notion à la culture, une évolution de la fonction et des catégories, Babel, no 33, 2016. 2- Emmanuel Molinet, La problématique de l'hybride dans l'art actuel, une identité complexe, le PortiQue, no 30, 2013. 3- Raphael Cuir, Hybridation \& art contemporain, AICA, 2013. Emmanuel Molinet

14 Bu konuda bkz: Gérard Genette, L'Oeuvre de l'art, immanence et transcendance, Seuil, 1994.

15 Yeni sanat yapıtı bildirisini açık seçik açıklamaz, yarım bildirir; kimi ipuçları verir, alıcının bildiriyi tamamlamasını bekler. Postmodernite alıcıyı bu perspektifte tanımlar.

16 Yapıtı biçimsel olduğu kadar anlamsal bakımdan çoğullaştırmanın en etkili yolu ayrışıklğa kapı aralayan metinlerarası unsurlara sıklıkla yer vermesidir.

17 Dolayısıyla Descartes'ın kesinlik anlayışı büyük ölçüde bir yana bırakılır.

18 Morris Weitz dans l'article "The Role of Theory in Aesthetics," The Journal of Aesthetics and Art 1 Criticism, (XV (1956), 27-35.)

19 Alıntılayan: Danielle Lories, Philosophie analytique et esthétique, Klincksieck, 1988, s. 34.

20 Nelson Goodman, Langages de l'art, J. Chambon, 1990; Manières de faire des mondes, J. Chambon, 1992.

21 Postmodernizm geçmişi yok saymaz, onun verilerini kendince yeniden değerlendirerek güncele taşır. Bu konuda bkz: P. Marie Rosenau, Postmodernizm ve Toplum Bilimleri, Bilim ve Sanat Yayınları, 1998. Ya da Madan Sarup, Postyapısalc1lık ve Postmodernizm, Pharmakon, 2017.

22 Bu kavramlar konusunda bkz: K. Aktulum, Metinlerarasılık/Göstergelerarasılık, Kanguru, 2011.

23 Yeni nitelemesi bir yapıtın, bağlamsal bir yer değiştirmeye bağlı olarak yapıttan bir kesitin biçimsel ve anlamsal olarak dönüşümü düşüncesini içermektedir.Yer değiştirme kavramı konusunda bkz: J. Kristeva, Sèméiotikè. Recherches pour une sémanalyse, Seuil, 1969.

24 Bu kavramlar konusunda bkz: K. Aktulum, Metinlerarası İlişkiler.

25 Burada metinlerarası bir çözümlemenin resim alanına uyarlanması söz konusu. Görselin alanına bir başka açıdan uyarlama konusunda özellikle bkz: 1- Liliane Louvel, Le tiers pictural: Pour une critique intermédiale (Interférences) Format Kindle, Presses universitaires de Rennes, 2016. 2- Bernard Vouilloux, Langages de l'art et Relations transesthétiques, l'Eclat, 1997.

26 Daha ayrıntılı bilgi için bkz: https://adadhannah.com/2009-the-raft-of-the-medusa-100-mile-house

$27 \mathrm{https} / /$ www.histoire-image.org/etudes/manifeste-romantisme

28 http://www.museejoliette.org/en/expositions/adad-hannah-en/

29 Life and Death in Hackney, 1999-2001. Adres: http://www.tomhunter.org/life-and-death-in-hackney/

30 https://ngpopgun.wordpress.com/2013/06/22/the-recreation/ 
31 http://www.tate.org.uk/art/artworks/millais-ophelia-n01506

32 Bu konuda ayrıntılı bir inceleme için bkz: K. Aktulum, Sinema ve Metinlerarasılık, Çizgi Yayınları, 2018.

33 Bu türden kavramların ayrıntıları için bkz: Lucien Dällenbach, le Récit Spéculaire, essais sur la mise en abyme, Seuil, 1977.

34 Latince "Tanrı'nın Kuzusu” adlamına gelir. Hıristiyan kültüründe, kendini kurban eden İsa peygamber için kullanılır. Aynı zamanda dinsel ayinler sırasında söylenen bir duadır.

35 Del Rio, 'Alchemies of thought in Godard's cinema', Substance 34 (3):62-78, 2005, s. 67.

36 Bu konuda bkz: http://www.kameraarkasi.org/light/teknikler/cesit/rembrand/rembrandtisigi.html

37 Bkz: Steven Jacobs, Framing Pictures, Film and the Visual Arts, Edinburgh University Press, 2011 , s. 112.

38 İsa, çarmıha gerilip Golgotha’ya götürülürken Veronica, alnını silmesi için ona örtüsünü uzatır. İsa, örtüyü alır, alnını sildikten sonra geri uzatır, İsa’nın yüzünün görüntüsü beze geçer.

39 Bu konuda bkz: Steven Jacobs, Framing Pictures, Film and Visual Arts, Edinburgh University Press, 2012.

40 Alıntılayan Fabien Ribéry, "La prise de Constantinople par les Croisés selon Jean-Luc Godard” http://www. tausendaugen.com/archives/ta09/cf7.pdf

41 A.g.y.

42 Bkz: http://www.rene-girard.fr/offres/doc_inline_src/57/

Marcel+Duchamp+mis + E0 + nu+par+Girard.pdf

43 Alıntılayan Fabien Ribéry, a.g.y.

44 Ya da bu konuda bkz: K. Aktulum, Sinema ve Metinlerarasılık, s. 115.

45 Düşsel Müze, André Malraux’nun bir denemesinin adıdır. Müze sanat yapıtıyla yeni bir ilişki biçimini açıklar. Bu ilişkide yapıtlar bilinen işlevlerinden koparılarak bir dönüşüme uğrarlar. Doğanın ya da birinin, olan ya da olmayan bir şeyin bir portresi portre olmaktan çıkar. Bir imge, görüntü olan sanat yapıtı müzede bir şeyi temsil etmekten uzaklaşır. Müze belleksel bir yerdir. Öznellikle bağlantılı tinsel bir işlev yerine getirir. Orası biçimlerin belleksel alanıdır. Bu anlamda, imgelem ve müze birbirlerine benzerler. Müze, imgesel olanla özdeştir. Orada dişsal olan içsel olanla buluşur.

46 Moser, Walter. 2007. "L'interartialité: pour une archéologie de l'intermédialité", in Marion Froger et Jüngen E. Müller (dir.). Intermédialité et socialité. Histoire et géographie d'un concept. Nodus Publikationen, s. 87.

47 A.g.y.

48 A.g.y.

49 Alıntılayan, Réda Bensmaïa, "Barthes/Godard: l'essai cinématographique est-il possible?", The Journal of Twentieth-Century/Contemporary French Studies revue d'études français, 4:2, 435-446, s. 435.

50 Palempsest imgesi konusunda bkz: K. Aktulum, Metinlerarası İlişkiler.

\section{Kaynakça}

Aktulum, K. (1999). Metinlerarası ilişkiler. İstanbul: Öteki.

Aktulum, K. (2011). Metinlerarasılık/Göstergelerarasılık. Ankara: Kanguru.

Aktulum, K. (2016). Resimsel alıntı. İstanbul: Çizgi.

Aktulum, K. (2018). Sinema ve metinlerarasılık. İstanbul: Çizgi.

Barthes, R. (1973). Le plaisir du texte. Seuil.

Barthes, R. (1970). S/Z. Seuil. 
Baumgarten, A.G. (1988). Esthétique. (Ed. de l'Herne)

Bensmaïa, R. Barthes/Godard: l'essai cinématographique est-il possible?. The Journal of Twentieth-Century/Contemporary French Studies revue d'études français, 4(2), 435-446.

Bonitzer, P., (1985). Peinture et cinéma: Décadrages, Cahiers du cinéma.

Cournarie, L. N. (2010). L'Art, l'esthétique en questions, Philopsis.

Del Rio, E. (2005). Alchemies of thought in Godard's cinema. Substance, 34 (3), 62-78.

Deleuze, G. (1969). Logique du sens (De Minuit, Ed.)

Eco, U. (2000). Açık yapıt (N. U. Dalay, Çev.) İstanbul: Can.

Genette, G. (1994). L 'Oeuvre de l'art, immanence et transcendance. Seuil.

Goodman, N. (1990). Langages de l'art. J. Chambon.

Goodman, N. (1992). Manières de faire des mondes. J. Chambon.

Jacobs, S. (2011). Framing pictures, film and the visual arts. Edinburgh University.

Lories, D. (1988). Philosophie analytique et esthétique. Klincksieck.

Mouillaud, G. (1965). Les essais de Jean-Luc Godard. in La Pensée. no 122, Août.

Moser, W. (2007). L’interartialité: Pour une archéologie de l'intermédialité. in Marion Froger et Jüngen E. Müller (dir.). Intermédialité et socialité. Histoire et géographie d'un concept. Nodus Publikationen.

Saussure, F. (2001). Genel dilbilim dersleri (B. Vardar, Çev.) Multilingual.

Weitz, M. (1956). Dans l'article the role of theory in aesthetics. The Journal of Aesthetics and Art 1 Criticism, XV, 27-35.

Zima, P.V. (2004). Critique littéraire et esthétique. Les fondements esthétiques des théories de la littérature. Harmattan.

\section{Elektronik Kaynaklar}

Ribéry, F., La prise de Constantinople par les Croisés selon Jean-Luc Godard. http://www. tausendaugen.com/archives/ta09/cf7.pdf

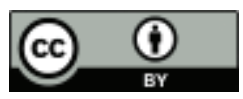

Bu eser Creative Commons Atıf 4.0 Uluslararası Lisansı ile lisanslanmıştır. (This work is licensed under a Creative Commons Attribution 4.0 International License). 